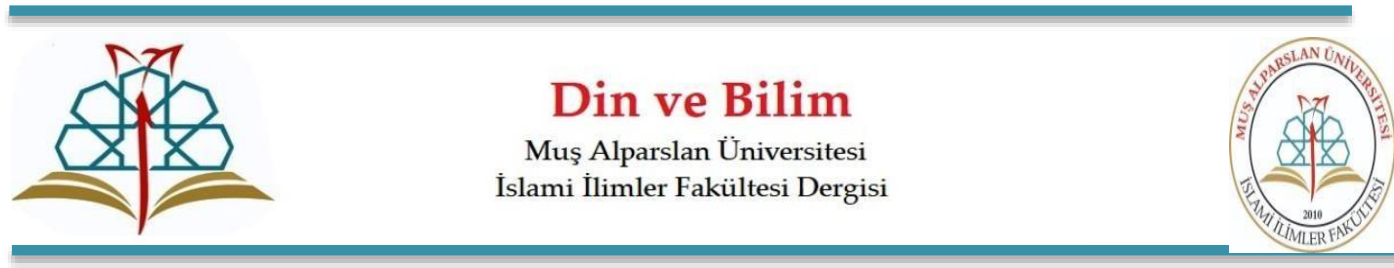

Din ve Bilim - Muş Alparslan Üniversitesi İslami İlimler Fakültesi Dergisi

Region and Science - Journal of Muş Alparslan University Faculty of Islamic Sciences e-ISSN: 2667-7717 Aralık/December 2020, 3(2): 6-28

\title{
İslam ve Demokrasi Tartışmaları Bağlamında Selefi Öğreti ve ‘Beşeri İdeolojiler' Retoriğinin Tarihsel Kökleri
}

The Salafist Doctrine in the Context of Islam and Democracy Debates and the Historical

Roots of 'Human Ideologies' Rhetoric

\section{Ertuğrul CESUR}

Dr. Öğr. Üyesi, Muş Alparslan Üniversitesi, İslami İlimler Fakültesi, İslam Mezhepleri Tarihi Anabilim Dalı.

Dr. Lecturer, Muş Alparslan University, Faculty of Islamic Sciences, Department of Islamic Sects, Muş/Turkey

e.cesur@alparslan.edu.tr

ORCID: 0000-0003-3915-8780

\section{Makale Bilgisi I Article Information}

Makale Türü / Article Type: Araştırma Makalesi / Research Article

Geliş Tarihi / Date Received: 27 Kasım/ November 2020

Kabul Tarihi / Date Accepted: 26 Aralık / December 2020

Yayın Tarihi / Date Published: 31 Aralık / December 2020

Yayın Sezonu / Pub Date Season: Aralık / December

DOI: $10.47145 /$ dinbil.832372

Atıf / Citation: Cesur, Ertuğrul. “İslam ve Demokrasi Tartışmaları Bağlamında Selefi Öğreti ve ‘Beşeri İdeolojiler' Retoriğinin Tarihsel Kökleri. / The Salafist Doctrine in the Context of Islam and Democracy

Debates and the Historical Roots of 'Human Ideologies' Rhetoric'. Din ve Bilim - Muş Alparslan

Üniversitesi İslami İlimler Fakültesi Dergisi 3/2 (Aralık 2020): 6-28. doi: 10.47145/dinbil.832372

İntihal: Bu makale, iThenticate yazılımınca taranmıştır. İntihal tespit edilmemiştir.

Plagiarism: This article has been scanned by iThenticate. No plagiarism detected. web: https://dergipark.org.tr/tr/pub/dinbil I mailto: dinbil@alparslan.edu.tr

Copyright @ Published by Muş Alparslan Üniversitesi, İslami İlimler Fakültesi / Muş Alparslan University, Faculty of Islamic Sciences, Muş, 49250 Turkey. Bütün hakları saklıdır. / All right reserved. 


\title{
Öz
}

Daha çok dışlayıcı bir söylem olarak bilinen Selefilik aslında İslam ilahiyatının da temel problematiğini teşkil eder. Ancak ortaya çıkışı İslam tarihinde erken dönem iç sorunları takip ettiğinden ve tartışmaya açıldığında tüm bu sorunları göğüslemeyi gerektireceğinden ilahiyat çevrelerinin bile çoğunlukla uzak durduğu bir konu olarak kalır. Tarihte "Selefi agresivite" 10. yy'da Eş'arilik tarafından bir "yumuşak geçişle" hafifletilebilmiş ve Eş'ari öğretiyi benimseyen devlet aygitınca baskılanmış ise de bu süreç analitik-sistematik tutarlılıktan çok politik hesaplaşmalar içinde gerçekleştiğinden sorun zaman zaman nüksederek yüzyıllar boyunca canlılığını korumayı başarmıştır. I. Dünya Savaşı'nın ardından uzun bir süre -en azından Türkiye'de- Selefilik gündemden düşer. Ancak 1950'li yıllardan itibaren yeni bir hareketlilik başlar. 1970'lerin sonuna kadar yıldan yıla artan çeviriler yoluyla Türkiye için de Selefilik adına "pasif" ancak yeni dinî düşüncenin şekillenmesinde belirleyici olan bir etkiden söz edilebilir. Öyle ki, dindarlığın Türkiye'ye özgü kültürel formlarını dahi dişlayan Selefi düşünceye bizzat muhafazakâr kesimlerde belli bir tepki görülür. Ancak yine sorunun özüne cevap vermekten hayli uzak bu tepkiler gerçekte bir "alan kapma" mesabesinde kalır. Bu dönem özellikle Seyyid Kutub ve Mevdudi gibi Neo Selefi isimlerin kitapları Türkçeye aktarılır. 1979 tam bir dönüm noktası olur. SSCB’ye karşı "Afganistan cihadı" başlarken Türkiye de 12 Eylül Darbesiyle Selefi yayın çevirilerinde adeta patlama yaşanır.

Anahtar Kelimeler: İslam, Kozmoloji, Selefilik, Eş'arilik, Demokrasi,

\begin{abstract}
Absract
Salafism, which has become known as an exclusionary discourse, actually constitutes the basic problematic of Islamic theology. However, since its emergence follows internal problems in the early period in Islamic history and will require confrontation with all these problems when opened for discussion, it remains a topic that it mostly avoids even in theological circles. Although "Salafist aggressiveness" in history was mitigated by the Ash'arism in the 10th century with a "soft transition" and suppressed by the state apparatus that adopted the Ash'ari doctrine, this process took place in political showdowns rather than analytical consistency, the problem sometimes recurred and kept its vitality for centuries has succeeded. Salafism disappears a long time- et least in Turkey- from the agenda after the First World War. However, a new dynamism starts from the 1950s. Through translations increased year by year until the end of 1970 for Turkey "passive" but on behalf of Salafism in shaping the new religious ideas it may be mentioned a decisive impact. Such that, to Salafism that excludes even the specific cultural forms of Turkey's religiosity, are seen react in certain conservative circles. However, these reactions, which are still far from answering the essence of the problem, remain in fact like "grabbing space". During this period, the books of Neo Salafist names such as Seyyid Kutub and Mawdudi were transferred to Turkish. 1979 becomes a real turning point. Against the USSR "Afghan Jihad" begins, after the September 12 coup in Turkey, there was a sharp increase in the translation of Salafi publications.
\end{abstract}

Keywords: Islam, Cosmology, Salafism, Ash'arism, Democracy,

\section{Giriş}

Daha çok dışlayıcı söylemleri ve son çeyrek asırda özellikle Müslüman coğrafyadaki eylemleriyle gündeme gelen Selefi hareketlerin ${ }^{1}$ "din dili" aslında İslam ilahiyatının da en temel problematiğini teşkil eder. Ancak tarihsel kökeninde erken dönem iç sorunlarla doğrudan ilgili olan Selefi öğreti tartışmaya açıldığında tüm bu sorunları göğüslemeyi gerektireceğinden ilahiyat çevrelerinde bile çoğunlukla etrafından dolaşılan bir konu olarak kalmaktadır. Kendisini dayandırdığı Hanbeli geleneğin tarihine bakıldığında aslında Selefi agresivitenin temellerine de inilmiş olur. Emevilerin yıkılmasının (750) ardından belli bir Ehli Hadis çevrenin yeni siyasi otoriteyi (Abbasiler) tanımama yönündeki tutumu Ahmed bin Hanbel (ö. 855) ile tam bir kutuplaşmaya dönüşür. Emeviler döneminde saray tarafından desteklenerek teşekkül etmiş rivayet kültürrü ${ }^{2}$ żzerinden dinin en iddialı

${ }^{1}$ Bkz. Mehmet Ali Büyükkara, Çağdaş İslami Akımlar, (İstanbul: Klasik Yayınları, 2015), 70.

2 Bkz. İbn Hacer Askalani, el İsabe fi Temyizi's Sahabe, (Beyrut: Mektebetü'l Asriyye, 2012), 5: 483. 
yorumu (ya da yorumsuz temsili) olma iddiasındaki bu çevreyle yaşanan gerilimin ardından Abbasi yönetiminin tavrı halife Mütevekkil döneminde (847-861) yumuşar. Ancak özellikle 10. yy.a gelindiğinde neden oldukları şiddet hareketleriyle yeniden sorun haline gelen Hanbelilik, siyaset ve ulema çevrelerinde daha köklü bir çözüm arayışına neden olur. Hanbeli tavır, bu dönem Mutezili öğretiyi terk edip Ehli Hadis görüşü benimsediğini deklere eden İmam Eş'ari (ö. 936) tarafından "içerden" bir "yumuşak geçişle" hafifletilmek istense de Hanbelilerin tavrı hiç de müspet olmaz. Fakat onun getirdiği bu açılım Hanbeliler konusunda devlet aygıtının tavrını da yansıtır. Sonuç olarak Hanbelilik ile kurulmaya çalışılan ilişki daha baştan tek taraflı ve felsefi tutarlılıktan çok politik hesaplara ve dengelere göre gerçekleşir. Böylece sorun devlet otoritesinin zafiyet gösterdiği dönenlerde nüksederek yüzyıllar boyunca canlılığını korumayı başarır. Modern dönemde ise Batı karşısında yaşanan gerilemeye paralel olarak İslam dünyasında meydana gelen siyasi otorite boşluğu sorunun, Vahhabilik/Selefilik suretinde yeni bir aşmaya evirilmesine ve I. Dünya Savaşı sonrası da Arap dünyasındaki din algısını ciddi şekilde belirlemesine imkân verir.

Osmanlı'nın parçalanmasıyla sonuçlanan I. Dünya Savaşı'nın ardından uzun bir süre -en azından Türkiye'de- Selefilik gündemden düsser. Ancak 1950'li yıllardan itibaren yeni bir hareketlilik başlar. 1970'lerin sonuna kadar yıldan yıla artan çeviriler yoluyla Türkiye için de Selefilik adına "pasif" ancak yeni dinî düşüncenin şekillenmesinde belirleyici olan bir etkiden söz edilebilir. Öyle ki, dindarlığın Türkiye'ye özgü kültürel formlarını dahi dışlayan Selefi düşünceye bizzat muhafazakâr kesimlerde belli bir tepki görülür. Ancak yine sorunun özüne cevap vermekten hayli uzak bu tepkiler gerçekte bir "alan kapma" mesabesinde kalır. Bu dönem çevirisi yapılmamış onca klasik temel eser dururken özellikle Seyyid Kutub ve Mevdudi gibi Neo Selefi isimlerin kitapları Türkçeye aktarılır. 70'li yılların ikinci yarısı Batı sistemi için Soğuk Savaş'ın sonuna gelindiğine ilişkin kesin kanaatler oluşur ${ }^{4}$ ve 1979 tam bir dönüm noktası olur. SSCB'ye karşı "Afganistan cihadı" başlarken Türkiye de 12 Eylül Darbesiyle yeni uluslararası duruma ayak uydurur.

80'ler, Selefi literatürün Türkçeye aktarımında adeta patlama yıllarıdır. Bu kitaplarda temel vurgu İslam adına "Kur'an ve Sünnet'e dayalı" bir yönetim kurmaktır. Bunun karşısında dünyadaki tüm rejimler, ideolojiler, felsefi akımlar ve kavramlar "beşeri"; yani "kifayetsiz insan aklının ürünüdür." Oysa olması gereken, her türlü sosyolojik sürecin ötesinde "ilahi yasalara" (Kur'an Sünnet) dayanmaktır. Yaşanan sorunlar "beşeri aklın ürünü" yasalardan kaynaklanmakta olup "Kur'an ve Sünnet'e dayalı yönetimde" bu sorunlar da kendiliğinden ortadan kalkacaktır! Hayatı okumada -klasik literatür açısından bakıldığında bile- oldukça yüzeysel bir "fıkıh jargonuna" dayanan bu metinlerde konu daha çok bir "yasa (hukuk) sorunu" olarak görülür ve "Allah'ın indirdiğiyle hükmetmeyenler kâfirdir" retoriği onca yayının özetidir. Kur'an ve Sünnet dişı addedilen her düşünce ve kavram reddedilmekle birlikte özellikle modern kavramlar "beşeri" ya da "Batıdan gelme" olduğu için kategorik olarak merduttur. Elbette "beşer aklına" dayalı bir siyaset kuramı olan, siyasi iktidarın "yedinci kat semadan" değil toplumdan (beşer) neşet etmesi gerektiği fikrine dayanan "demokrasi" kavramı da bu kategoride baş düşman (küfür) olup hangi parti için olursa olsun "oy kullanmak" dahi "imandan çıkma" mesabesinde din dışıdır. ${ }^{5}$

Son derece basit olmasına karşın ciddi bir tarih-sosyoloji bilgisi olmayan, kültür düzeyi düşük gençler ve kimi gayrı memnun unsurlar için oldukça "anlaşılır" ve cazip bu "muhalif" söylem tüm keskinliğiyle 80'li yıllarda pasifizmden çıkmaya, daha eylemsel bir tavra yüz tutar. Sovyet sisteminin çöktüğü 1990'larla yeni bir dönemin kapıları aralanır. Yeni Dünya Düzeni şartlarında Selefi öğreti mantıksal sonuçlarına erer ve Afganistan'da dahi daha önceki yapılardan çok daha agresif bir hareket

\footnotetext{
${ }^{3}$ Bkz. Hikmet Yağlı Mavil. "Eş'ariyye'nin Kurucusu Ebü'l-Hasan el-Eş'arî". Uludă̆ Üniversitesi İlahiyat Fakültesi Dergisi, (Haziran 2012), 21/2: 89.

${ }^{4}$ Bkz. Şerif Mardin, Din ve İdeoloji, (Ankara: Sevinç Mtb. 1969), 5.

${ }^{5}$ Bkz. Mehmet Metiner, Yemyeşil Şeriat, Bembeyaz Demokrasi, (İstanbul: Karakutu Yayınları, 2008), 93.
} 
olarak Taliban suretinde somutlaşır. 2000'li yıllara gelindiğinde Afganistan sınırlarını da aşar ve önce El Kaide, sonra IŞ่iD ile kan donduran beynelmilel eylemler başlar. Tüm bu süreçte Türkiye muhafazakârlığı, dünya medyasındaki kötü şöhreti ve "tekfirci" söylemleri nedeniyle Selefi yapıları sahiplenmez ancak teorisi yazılmış bir karşıtlık da sergilemez. Muhafazakârlığın tekfircilikten sakınabilmesinin nedeni, Selefilikten ayrıştığı temel kaynaklara dayalı, tutarlı bir teoriye sahip olduğundan değil, tarihsel tecrübeler sonucu yoğurularak gelişmiş belli bir sağduyu ve "refleks" geliştirmiş olmasıdır. Ne var ki, çözmek yerine üzerinden atlanarak modern zamanlara kadar gelmesine göz yumulan sorunlar zaman zaman sağduyunun dahi baş edemediği ve hatta kötüye kullanıldığı durumlara neden olur. Pek çok alanda görülmesi mümkün olan bu sorunsalın en tipik yansıması, demokrasi kavramına ilişkin muhafazakâr isteksizliktir. Onlarca yıldır Să̆ muhafazakâr partilerin "demokrasi" konusundaki iddialı söylemleri dahi muhafazakâr tabanda bu kavramın içselleştirilmesinde en ufak bir etki uyandıramadığı gibi en ılımlısından en aşırısına dinî cemaatlerin demokrasi kavramını açıkça "din dışı" niteledikleri sıklıkla görülür. Bu hengâmede Sağ siyasilerin demokrasi konusundaki olumlu ifadeleri yazılı kültürde çok da konu edilmez, siyaseten söylenmiş kabul edilir. Yapılan izahtan anlaşılacağı üzere sorunun özüne ulaşmak için aslında modern dönem sonuçlarından çok klasik dönem köklerine inilmesi gerekmektedir. Fakat ondan önce muhafazakâr taban tarafından bu kadar şeytanlaştırılan "demokrasi" kavramının kısaca tarih ve felsefesine bakmakta da fayda var.

\section{Demokrasinin Mantığı ve Kozmolojik Temelleri}

Bilindiği üzere demokrasi kavramının kökleri antik Yunan'a gider. Modern dönemde ise Avrupa tarihinde Aydınlanma düşüncesine dayanır. ${ }^{6}$ Ancak felsefi temellerine inildiğinde kavramın modern anlamıyla, tarihte insanoğlunun benzer sorunlara cevap ararken benzer sonuçlara varmasının Batıdaki tezahüründen ibaret olduğu görülür. Tarihi bilgilerin de gösterdiği üzere kadim zamanlardan beri insan toplulukları (boy, kabile, klan vb.) kendi içlerinde alt kollara bölünür ve böylece aynı soyun alt kümeleri şeklinde yeni akraba topluluklar oluşur. Alt kollar genellikle daha dar ve ilişkiler hala çok daha iç içe olduğundan liderlik görevinde doğal olarak doğrudan kişinin kendisinden gelen karizma, tecrübe (yaş), bilgelik, kahramanlık gibi vasıflar öne çıar. ${ }^{7}$ Bu durum diğer akraba alt boylarda da işler ve böylece bu vasıflı liderlerin bir araya gelmesiyle tüm boyu temsil eden bir "meclis" (toy /kurultay /şura /konsül) teşekkül eder. Bu mecliste de "eşitler arası birinci" (Lat. Primus inter pares) olarak boyun geneli için bir lider (bey, emir, lord) seçilir. Böylece liderlik alt boylardan birinde olsa da tüm farklılıkların temsil edildiği bir mekanizma (idare) işler. Demokrasi kavramının geldiği Antik Yunan'ın şehir devletleri de böylesi bir yönetim sisteminin -kendi şartlarındaoldukça gelişmiş bir örneğidir. ${ }^{8}$

Bu siyasi - sosyal mekanizmanın tüm kültürlerde kozmolojik - teolojik açılımı da vardır. Bilindiği üzere Orta Çă̆'ın sonuna kadar insanoğlunun içinde yaşadığı dış dünyaya ilişkin kabulleri nesnel bilgiye dayalı sistematik düşünceden çok duyularının sınırlarında şekillenmiş algılarına dayalı efsanevi anlatılardan oluşmaktadır. Dünya merkezli bu evren modeli matruşka gibi "iç içe geçmiş katmanlı kürelerden" oluşur. Bu sistemde "tanrının mekânı" en üst katmandır ve yeryüzündeki egemenliğin kaynağı da oradan gelir. Eski Türklerde hükümdarlık makamına seçilen kağan toyda "kut" alır yani; göksel bir yetki olarak kendisine beylik verilir. ${ }^{9}$ Toy, "gök tanrı" adına kut vekilini belirler. ${ }^{10}$ Kağan, toyda yapılan istişare sonucu tüm boyların görüşü alınarak seçilir. Toy, kağanı seçtiği gibi görevden de alabilir. Buna göre toy kağanın da üzerindedir. Göktürklerde toy, İrteriş

\footnotetext{
${ }^{6}$ Jean François Kervegan, “Demokrasi”, Siyaset Felsefesi Sözlü̆̆̈̈, trc. İsmail Yerguz, (İstanbul: İletişim Yayınları, 2011$), 192$.

${ }^{7}$ Bkz. İbn Haldun, Mukaddime, (Beyrut: Dâru'l Fikr, 2001), 1: 332.

${ }^{8}$ Bkz. Ulrich Wilcken, Griechische Geschichte im Rahmen der Altertumsgeschichte, (München: R. Oldenbourg Vrl., 1973 ), 26.

9 Sait Başer, Kutadgu Bilig'de Kut ve Töre, (İstanbul: İrfan Yayınları, 2011), 18.

${ }^{10}$ Bkz. Yaşar Bedirhan, İslam Öncesi Türk Tarihi ve Kültürü, (Konya: Eğitim Yayınları, 2019), 94-95.
} 
Kağan'ı tahttan indirmiş, yerine Ozmış Kağan'ı tayin etmiştir. Avrupa'da da benzer yapılar görülür. Frankların erken döneminde "Gaukönige" adı verilen Cermen boylarının liderlerinin yanında kralın "eşitler arası birinci" statüsü vardır. ${ }^{11}$

Ancak zamanla ülke genişler (boy devleti olmaktan çıar), fetihlerle zenginleşir ve boyun beyinde, "monarşik eğilimler" baş gösterir. Böylece diğer alt beyler mutlak otorite karşısında birincil tehdit olarak görülür ve bir bir tasfiye edilir. Artık bir "genel meclis" yok, sadece bürokratik bir mekanizma olarak kralın memurlarından ibaret "idari kurul" (divan) vardır.12 Genişleyen sınırlar ve artan nüfus, alt beyler için krala ulaşmakta bir engele dönüşür. Bundan böyle hükümdarlığın el değiştirmesi de seçimle (meclis) değil, "babadan oğula" gerçekleşir. Hükümdar akraba boylara güvenemediğinden işleri tahtına göz dikemeyecek yabancı unsurlardan asker (devşirme) ve bürokratlarla yürütür. Tüm bu süreci İbn Haldun (ö. 1406) şöyle özetler:

Devlet ikinci devresinde bulunduğunda onları istibdadı altına alarak hükümdar ululuğu ancak kendi şahsında topladıktan ve onları devlet işlerini ortaklaşmaktan uzaklaştırdıktan sonra devleti kuran bunlar hükümdarın düşmanı olurlar. Hükümdar bunların kuvvetini kırarak devlet idaresinden uzaklaştırmak için kendi neslinden olmayan yardımcılar aramağa mecbur olur. Bu yabancı kuvvetler onlara galebe çalar, bu yabanciları memuriyetlere tayin eder. ${ }^{13}$

Artık genel meclis ile işi olmayan hükümdar otoritesinin meşruiyeti için yeni argümanlara ihtiyaç duyar. Bu maksatla inanç sistemi yorumlanarak mutlak otorite için kozmolojik - teolojik mesnetler üretilir ve sonuçta hükümdarın doğrudan "tanrı tarafından seçildiği" tescillenir. Artık "kut" toplumu temsil eden meclis kanalıyla değil, doğada; dış dünyada görüldüğü iddia olunan "yıldız kayması", "güneş tutulması" gibi olağanüstülükler, dinî-kozmik semboller ya da -ucu tanrıya uzanan- kutsal ataların asil soyundan (kutsal kan, nesep, Kureyşilik vb.) gelme gibi "seçilmişlik" göstergelerinde aranır. Sonuç olarak tanrı ile hükümdar arasında toplumsal irade ve temsilcisi meclis bay-pas edilmiş, hükümdar doğrudan yedinci kat semadaki tanrının yeryüzündeki vekili olmuştur. Artık hükümdarın iradesi, tanrının iradesinin yansıması olup tanrının yeryüzüne yansıyan silueti, gölgesi vb. anlamında "lakaplar" (sıfatlar) alır. Bu şekilde kozmik-ontolojik delillerle temellendirilmiş "pederşahi" (patrimonyal) yönetimde mülk (devlet) tanrının, tanrı adına da hükümdarındır. Bu tanrısal temsil iddiası dünyanın dört biryanında sayısız söylenceye konu olmuştur.

\section{2. İslam'1n Siyaset Felsefesi}

Aslında pratik gerçeği "monarşiden" ibaret olsa da Mart 1924'te Hilafetin ilgası İslam dünyasında büyük bir boşluk hissi uyandırır. Bu durum karşısında Mısırlı Ali Abdurrazık daha 1925 yılında yayınlanan İslam'da Ikktidarın Temelleri- الإسام وأصول الحكم kitabında, "İslam'da belli yönetim biçiminin olmadığı" görüşünü dile getirerek bir anlamda olayı normalleştirmeye çalışır. ${ }^{14}$ Kitap kendi döneminde büyük bir öfkeye neden olmuş ve yazara pahalıya patlamışsa da zamanla Abdurrazık'ın görüşü yaygın kanaat haline gelir. Ancak bu kanaat aslında Abdurrazık'ın kitabının içeriğiyle kıyaslandığında son derece "indirgeme" kalmaktadır. Zira küçük hacmine rağmen eserin içeriği bugünden bile İslam düşüncesine ilişkin çok ileri bir siyaset felsefesi tartışması yapmaktadır. Kitapta halifenin yetkisinin doğrudan yedinci kat gök semasında olduğuna inanılan Allah katından mı, toplumdan mı geldiği gibi konuları oldukça yetkin bir dille tartıştığı görülmekte, aynı tartışmanın Orta Çağ sonlarında Avrupa'da da yapıldığına dikkat çekilmektedir. ${ }^{15}$

\footnotetext{
${ }^{11}$ Bkz. Heinrich Dannenbauer, Grundlagen der Mittelalterlichen Welt, Skizzen und Studien, (Stuttgart: W. Kohlhammer Vrl., 1958), 173.

${ }^{12}$ Bkz. Mehmet İpşirli, “Osmanlı Devleti'nde Kazaskerlik, (XVII. yüzyıla kadar)”, Belleten, 61/232 (1997), 680.

${ }_{13}$ İbn Haldun, Mukaddime, 1: 229.

14 Bkz. Mehmet Görmez, "İslam Dünyasında Laiklik Tartışmasını Başlatan Bir Kitap ve Bu Kitabın Serencamı”, İslami Araştırmalar Dergisi, (Yaz-Güz 1985), 8/3-4, 225.

${ }^{15}$ Bkz. Ali Abdurrazık, İslam'da İktidarın Temelleri, trc. Ömer Rıza Doğrul, (İstanbul: Birleşik Yayınları, 1995), $31-32$.
} 
Bilindiği üzere yedi kat gök (seba semavat) kozmolojisi İslam öncesi Arabistan yarımadası için de geçerlidir. Son derece katı kabile düzeninin hâkim olduğu yarımada ciddi şekilde Sasani kültürünün etkisinde olup düalist bir metafizik hâkimdir. ${ }^{16} \mathrm{Bu}$ şartlarda ortaya çıkan İslam tüm bu metafiziği değiştirdiği gibi siyasal meşruiyette "tanrısal temsil" iddialarının dayandığı kozmoloji algısında da ciddi revizyonları gerektirir. Kur'an Hz. Peygamber'in vahye muhatap oluşunu ne onun soyuna nispet eder, ne de doğaüstü kabiliyetlerine. Hz. Peygamber'in Allah tarafından muhatap alınışı onun "ahlakına" dayandırılır."17 Bunun dışında kendisinde hiçbir insan ötesi durum yoktur. (Ben de sizin gibi bir beşerim.) ${ }^{18}$ Böylece sınıflı toplum düzenlerinin temel dayanakları (kutsal kan, ilahi soy, metafizik güç vb.) açıkça reddedilir. Bilindiği üzere uyarlık ile barbarlık arasındaki en temel fark yazılı kültürle geçilmesidir. ${ }^{19}$ Cahiliye Arapları gibi yazılı hukuk kurallarının olmadığı, düzenin kabileler arası dengeye dayandığı toplumlarda güçlü olan haklıdır. Uygar toplumda ise haklılık bireylerin ait olduğu grup, kabile vb. güç merkezleri arasındaki dengeye göre değil, herkesin altında imza koyduğu, ayrımcılık gözetilmeyen normlardan ortak yazılı sözleşmeden alır.

\subsection{Hz. Peygamber Pratiğinde İdeal Toplum Olarak Ümmet}

Hz. Peygamber'in Yesrib'e hicretinden sonra ilk yaptı̆̆ı iş bir "yazılı belge" ile kentteki tüm unsurları bir arada yaşayabilecekleri ortak bir paydada buluşturmak olur. Son derece eşitlikçi adilane ilkelerden oluşan belgede bir ümmet tarifi de görülür. Bu tarifin sadece Müslümanları değil, belgeye imza koyan herkesi kapsadığı açıkça görülmektedir:

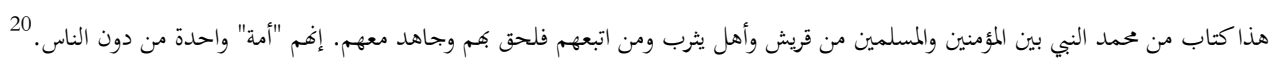

Bu, Kureyşli Müminler ve Müslümanlar ile Yesribliler ve onlara tabi olanalar ve onlardan sayllanlar ve onlarla birlikte savaşanlar arasında Peygamber Muhammed (as) tarafından (yazdırılmış) vesikadır. Bunlar, diğer insanlardan ayrı tek bir "ümmet" teşkil ederler.

Bundan böyle Yesrib şehri bir "Medine" vasfı kazanmıştır. Medine bir çeşit "cumhuriyet" anlamındadır. Hz. Peygamber'in bu pratiğinden hareketle ümmet kavramı için belli bir coğrafyayı yurt edinmiş, birbirlerinin hukukuna saygı çerçevesinde bir arada yaşama idealini yansıtan bir yazılı belgeye imza koymuş, bu belgeyi iktisadi ve askeri olarak da koruyabilecek güce sahip topluluk olduğu söylenebilir. Öyle ki Medine'de yaşayan ve bu belgeye imza koyanlar ümmetten sayıldığı halde, Müslüman olup hala Hicret etmemiş olanlar ümmet mefhumunun dışında tutulmaktadır: "İman edip de hicret etmeyenler ise hicret edinceye kadar onlarla sizin bir velayetiniz yoktur."21

Tüm bunlar göz önünde bulundurulduğunda kavram günümüzde ulus/millet (nation) kavramına tekabül etmekte olup modern Arapçada da ümmet kavramı "ulus" anlamında kullanılmaktadır (ör. الامم المتحدة - Birleşmiş Milletler). Buna göre ne coğrafi sınırları belli, ne de askeri, siyasi, iktisadi bir birlikteliğe dayalı ortak metni olan milyarlarca insanı "ümmet" kavramı üzerinden konsolide etme iddiasının İslam'ın temel metinlerinde karşıllğı olmayan, İbn Teymiyye'den (14. yy.) daha öncesine gitmeyen, modern dönemde neo emperyalist hesaplarla kurgulanmış karanlık yapıların korsan temsilciliğinden ibarettir. Müslüman ülkelerin (ulus devletlerin) dayanışması ve hatta üst ittifaklar oluşturması başka bir şeydir, ülkelerin sınırlarını, hukuk düzenlerini tanımayan, karanlı ilişkilerden beslenen anarşist/kozmopolitist enternasyonalizm başka. Kavramın felsefi anlamına bakıldığında da çoğunlukla zannedilenin aksine bir "çokluk" değil; Kur'an'da ifade edildiği üzere "azlık" vurgusu vardır. İnsanlığın her türlü zorbalıktan uzak, herkesin hakkının güvence altına

\footnotetext{
16 Bkz. 16. Nahl, 51.

17 68. Kalem, 4.

18 18. Kehf, 110

${ }^{19}$ Hildegard Elsner \& Hans Reichardt, Die Germanen, (Nürnberg: Tessloff Vrl., 2008$), 7$.

20 İbn Hişam, es Siretü'n Nebeviyye, (Beyrut: Darü'l Kitabil Arabi, 1990), 2: 143.

21 8. Enfâl, 72.
} 
alındığı bir ideal toplum düzeni bu uğurda idealist insanları gerektirir. Toplumunda yalnız kalan $H z$. İbrahim "tek başına ümmettir." 22 Kur'an, aslında her zaman azınlık olarak kalmaya mahkûm bu idealizmi ayakta tutmaya çağırır: "Sizden; hayra çă̆ıran, iyiliği telkin eden ve kötülükten sakındıran (az da olsa) bir topluluk (ümmet - أمة) bulunsun." 23

\subsection{Toplumcu Bir Kuram Olarak Hilafet}

Ümmet tanımından anlaşılacağı üzere İslam'ın siyaset felsefesi, varlık şuuru son derece güçlü bireyleri gerektirir. Böylesi güçlü bir birey imgesine "akıl" vurgusunun eşlik etmesi tesadüfi değildir. Davranışlarını mensubu olduğu gruba endeksleyen kabile düzenine bireyler bilinçli tercih yapmaya çağırılır. ${ }^{24}$ İslam'ın bu güçlü birey vurgusu Kur'an'ın insan felsefesini anlatan Hz. Âdem'in yaratılış kıssasında çok daha belirgindir. ${ }^{25}$ Yeryüzünde Allah adına tasarrufla görevlendirilen insan ${ }^{26}$ toplumsal düzen için de yetkilendirilmiştir. ${ }^{27}$ Âdem'in şahsında "insan türü" 28 kast edilmiştir. Buna göre tüm insanlar için "Allah'ın halifesi" sıfatı geçerlidir. Kavramın bir diğer kullanımı ise Davut Peygamber hakkındadır. ${ }^{29}$ Buradaki ise liderin topluma vekâleti (hilafeti) anlamındadır. Kur'an'da yönetimle ilgili bir diğer esas da "şura" ilkesidir. ${ }^{30}$ Tüm bunlar göz önünde bulundurulduğunda iktidarın kaynağına ilişkin -bugünden bakıldığında bize oldukça aşina gelecek- şöyle bir temsil hiyerarşisi oluşur:

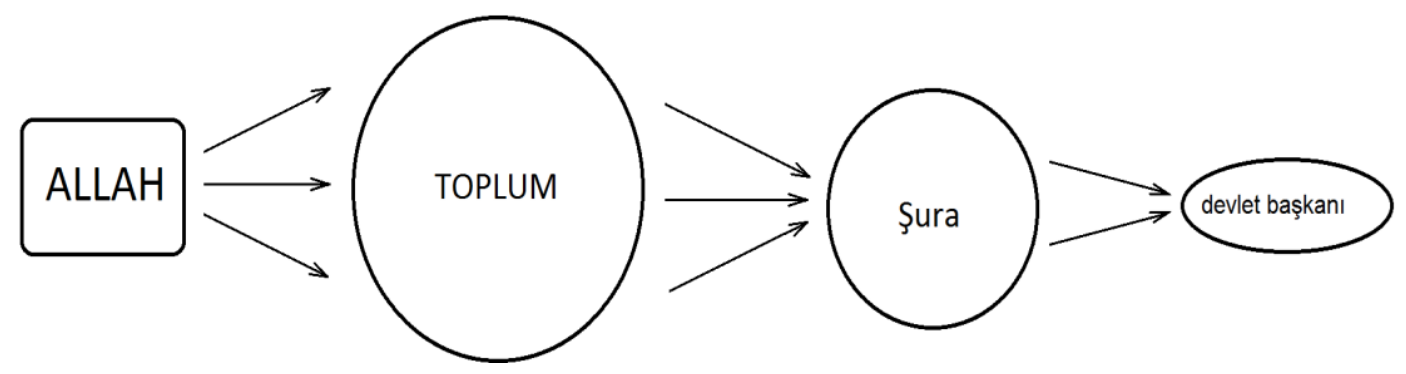

\section{Tulekâ'dan Hulefaya Emeviler ve "Beşer'in Hükmü"}

Kabileciliğin en kesif şekliyle hüküm sürdüğü Arabistan çöllerinde her türlü çıkar ilişkilerini aşıp böylesi yüksek idealleri hayata geçiren Müslümanlar tarafından, Ebu Süfyan liderliğindeki Kureyşli müşriklerin direnci kırılarak nihayet Mekke de alınır (630). Şehrin kontrolü sağlandıktan sonra aslında müşrikler savaş hukuku gereği köle alınmaları ya da idam edilmeleri gerektiği halde kendilerine büyüklük gösterilir ve Hz. Peygamber'in “gidin, tulekâ'sınız (اذهبوا فانتم الطلقاء) sözüyle serbest bırakılırlar. ${ }^{31}$ Fetihten sonra Ebu Süfyan'dan karısı Hint'e hepsi “Müslüman” olmuştur. Ancak "tuleka" olarak samimiyetleri tartışmalı kalacaktır. Bu durum Kur'an'da da fetih öncesi ve sonrası arasındaki farka işaret edilerek vurgulanır: "Fetihten önce infak edip savaşanlar elbette (sonrakilerleltulekâ) bir değildir. Onların dereceleri, daha sonra infak eden ve savaşanlardan daha büyüktür." "32

Buna göre tulekâ "iman derecelendirmesi" ifade etmesi bakımından bir anlamda "Pro-Kelam" bir "akait kavramı" olarak değerlendirilebilir. 632 yılında Hz. Peygamber de ömrünün ahirine erer ve

\footnotetext{
22 16. Nahl, 120.

23 3. Ali İmran, 104.

24. Bakara, 170 .

25 2. Bakara, 30 .

${ }^{26}$ Rafii, el-aziz Şerhü'l Veciz, (Beyrut: Darü'l-Kütübi'l-İlmiyye, 1997), 13.

${ }^{27}$ Bkz. Rafii, el-aziz Şerhü'l Veciz, 18.

${ }^{28}$ Zemahşeri, Keşşaf, (Riyad: Mektebetü'l Abikân, 1998), 1: 251.

29 38. Sad, 25.

30 42. Şura, 38.

${ }^{31}$ Taberi, Târîhu'r Rusül ve'l Mülûk, (Kahire: Dârü'l Me'ârif, 1967), 3: 61.

32 57. Hadid, 10.
} 
hayata gözlerini yumar. Ne var ki, ondan sonra Müslümanlar çok da iyi bir sinav veremezler. Hz. Peygamber'in vefat ettiği gün olacaklar sezinlenmektedir ki ilk hareket, siyasi iktidarda söz sahibi olabilme adına erken davranmaya çalışan Ensar'dan gelir. Ancak "Kureyş kabul etmeyeceği" gerekçesiyle Ensar kolaylıkla siyaset dışı bırakılır. ${ }^{33}$ Kureyş'in özellikle en iddialı olabilecek Haşmi kolu da "aceleye getirilen" süreçte yok sayılır. Daha sonra bu aceleciliğe ilişkin rahatsızlık dillendirildiğinde şartlar gereği "oldubittiye getirildiği" söylenecektir." 34

Gerekçe ise ilk halifenin Haşimilerden (Hz. Ali) olması durumunda bunun nübüvvetle hilafetin Haşimiler'de birleşmesine yol açacağı ve öyle de devam edeceği endişesi olduğu şeklinde açıklanır. ${ }^{35}$ Buna göre iktidar Kureyş'ten olmalı, ancak Haşimiler'den olmamalıdır. Beyat krizine rağmen Hz. Ebu Bekir (Kureyş/Teym oğulları) ve Hz. Ömer (Kureyş/Adi oğulları) dönemleri nispeten sakin ve istikrarlı geçer. Ancak Kureyş'in Emevi oğullarından Hz. Osman dönemine gelindiğinde iş değişir. Çoğu "tulekâ" olan Emeviler durumu fırsat olarak görür. Emevi valilerin zulümleri Mısır, Basra ve Küfe'de isyanlara neden olur. Nihayet 656 yılında eyaletlerden gelen gruplarca kuşatılan Medine'de yaşanan çatışmalarla Hz. Osman yaşamını yitirir. ${ }^{36}$ Bu kaos ortamında Hz. Ali halifeliği kabul etmek durumunda kalır. Fakat devlet içinde devlet olmuş Şam valisi Muaviye, Hz. Ali'nin hilafetini tanımaz, yeniden çatışma baş gösterir. Bundan sonra olacak olaylarla ilgili Taha Hüseyin'in şu sözleri dikkat çekicidir:

...İslam, Arap yarımadasında gerçekten Arap aklını tümüyle İslami bir akla dönüştürmeyi başardı mı, doğrusu kuşkuluyum. İslam'ın Arap yarımadasında çok şeyi değiştirdiği kesin ancak birçok Arap'ın kalbine ulaşamadığı da kesin. Allah Teâlâ'nın şu sözünde dediği gibi: "Bedeviler, küfür ve nifak bakımından daha şiddetlidirler..." Bu ayet sadece Hz. Peygamber dönemi Bedevileri ile sinırlı değil, Hulefa-i Raşidin, Emevi ve Abbasi dönemleri için de geçerlidir... ${ }^{37}$

Sıffın'da (657) savaş lehine giderken Hz. Ali'nin iyi niyet gösterip Muaviye tarafının -harp hilesi"hakeme gitme" teklifini kabulü, geri dönüşü olmayan teolojik ayrışmaları tetikler. Hz. Ali safında savaşan ve daha sonra Hariciler olarak adlandırılacak bedevi kabileler hakeme gitmeyi "Allah'ın hükmü" yerine "beşer sözüne itibar etme" olarak görür ve Hz. Ali'den ayrılırlar. ${ }^{38}$ "Hüküm Allah'ındır - ان الحكم الا لهُ "söylemiyle tahkimi kabul eden herkes "kâfir" ilan edilir. Yaygın kanaat Haricilerin "hüküm Allah'ındır" demekle, "Kur'an'ı hakem yapmak istedikleri” şeklindedir. Oysa Kur'an'ın (mushaf) bir "kitap" (obje) olduğu ve bizzat konuşmayacağı (hakemlik yapamayacağı) Hariciler açısından da açık bir durumdur. Hatta Hariciler Kur'an'dan gösterilen delilleri reddetmişlerdir. Hz. Ali ikna için Abdullah bin Abbas'1 Haricilere gönderir. İbn Abbas hakem olayının meşruluğunu anlatmak için Kur'an'daki, "karı-koca arasındaki ihtilaf" 39 ve "ihramlıyken av hayvanı öldürme" 40 konularındaki "hakem" emrini gösterir. Buna göre "beşerin hükmüne uyma" bizzat Kur'an'da yer alan, hatta emredilen bir konu olmaktadır. Hariciler İbn Abbas'1, "Siz Müslümanların kanını av hayvanı ve karı - koca ihtilafıyla bir mi tutuyorsunuz" diyerek geri çevirirler. ${ }^{41}$

Bu itirazda Arapların İslam öncesi adetlerine bir gönderme olduğu açıtır. Bilindiği üzere İslam öncesi düalist bir dünya görüşüne sahip olan Araplar evrende "iyicil" ve "kötücül" iki gücün çatışma halinde olduğuna, bu çatışmanın, dünyada tarihin akışına bir çeşit "yazgı" şeklinde yön verdiğine

\footnotetext{
${ }^{33}$ Ahmet Cevdet Paşa, Peygamberler ve Halifeler Tarihi, (İstanbul: Merve Yayınları, tarihsiz), 1: 196.

34 İbn Asâkir, Târîhu Medîneti Dımaşk, (Beyrut: Daru'1 Fikr, 1995), 30: 283.

35 İbnu'l Esir, el Kâmil fi't Tarih, 2: 458.

36 İsmail Yiğit, “Osman”, Türkiye Diyanet Vakfi İslam Ansiklopedisi, (İstanbul: TDV Yayınları 2007), 33: 441.

${ }^{37}$ Taha Hüseyin, Min Târih el Edeb el Arabi - el Asru'l Abbâsîyyi el Evvel, (Beyrut: Dâru'l İlm li'l Melâyîn, 1971), $2: 9$.

38 Salim b. Zekvân el Hilali, es Sîre, trc. Harun Yıldız, (Ankara: Ankara Okulu Yayınları, 2017), 65.

39 4. Nisa, 35.

40 5. Maide, 95.

${ }^{41}$ İbnü'l Esir, el Kâmil fi't Tarih, (Beyrut: Daru'l Kutubu'l İlmiyye, 1987), 3: 203.
} 
inanıyor ve buna "Dehr" diyorlardı. Barışçl durumlarda ya da sorunda bir karşı taraf bulunmadığında "fal bakmak" (fal okları vb.) Dehr'in sonucunu tespit için yeterliydi. (Abdulmuttalib'in kurban yemini bozmak için oğlu Abdullah ile diyet miktarı develer arasında kura çekmesi gibi). Ancak olayın tarafları varsa iş biraz daha karışık bir hal alıyordu. Bu durumda bir seçenek, hakeme gitmekti. (Kabe'nin onarımında Haceru'l Esved için Hz. Peygamber'in hakem olması gibi). Ancak ihtilaf kan davaları gibi büyük olaylarda dönüşmüşse hakem de tercih edilen bir yöntem değildi. Bu durumda iki taraf çatışır, kararın "Dehr" tarafından verilmesi beklenirdi. Dehr hükmünü kılıçla (حكم السيف) savaş meydanında verir, sonuçta bir insan (beşer) olan hakemin olası hilesine, tarafgirliğine vb. fırsat verilmemiş olurdu. Muhadramun şairlerden eş Şemeyzer el Hârisi şöyle der:

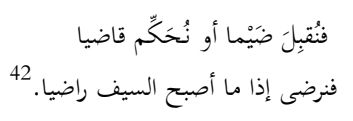

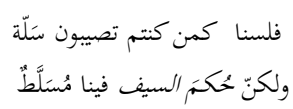

Rüşvet almış değiliz ki,

Kılıcın hükmü aramızda hakem,
Baskınıza, yargınıza olalım razı.

Kılıç neye razıysa, ona oluruz razı.

Yeniden ihya edilen düalist (Dehri) külte göre43 Sıffın'da da "hüküm" hakeme gitme yoluyla değil, savaş meydanında aranmalıydı. Alınan galibiyetle "Allah'ın hükmü" tecelli edecek, kimin meşru olduğuna savaş meydanda kılıcın hükmüyle karar verilmiş olacaktı. Fakat olan olmuş; Hz. Ali öldürülmüş (661) ve Muaviye'nin "hilafet" yolu açllmıştır. Muaviye tüm bunları -Fetih Suresine atfen* şöyle yorumlar:

$$
\text { المنصور من نصره اللة، والمهزوم من خـذله اللة. }
$$

Kazanan, Allah'ın yardım ettiği, kaybedense Allah'ın terk ettiğidir. ${ }^{44}$

Başka varyantları da görülen bu ifadedeki خذل sözcüğü Kur'an'da, "Allah'ın yardımını kesmesi" anlamında kullanılır. ${ }^{45}$ Muaviye'ye göre yaşananlardan "halife" olarak çıkması, "Allah'ın kendisine yardımı" ve "Hz. Ali'yi yardımsız bırakması" neticesidir. Buna göre Haricilerin "hüküm Allah'ındır" görüşü de aslında gerçekleşmiş; neticede Muaviye sultan olmuştur. Bundan sonra İslam'ın kavimler üstü, toplumsal temsil temelli siyaset felsefesinin yerini hızla Cahiliye döneminin güç (kabile) dengesi esaslı düzeni alır. Elbette bu durum tarihi gerisin geri çevirmek şeklinde olmaz. Yaşananlar Muaviye'nin meşruiyetine ilişkin bir "ilahi işaret" toplumsal temsil için bir mekanizmaya (şura vb.) gerek yoktur. Bu yöndeki rivayetlerde "hilafetin 30 yıl olacağı, ondan sonra saltanata geçileceği" 46 bir yazgı olarak öngörülmüş olur. Ne var ki işareti alan Muaviye orada da kalmaz, bu sefer de oğlu Yezid'i "veliaht-halife" tayin eder ve bu kararı da Allah'ın yazgısıdır:

$$
\text { انّ امر يزيد قضاء من القضاء، وليس للعباد الخيرة من امرهم. }
$$

“Yezid'in işi kesinleşmiş bir hükümdür. Kullara seçme hakkı yoktur."

\section{Arapça'nın Kıdemi ve Kavmiyetçi Teoloji}

İnsanlardan bağımsız ezelden belirlenmiş bir "yazg1" ve "temsil” öğretisine karşı çıkan muhalifler Allah'ın olacakları önceden belirlediği fikrini reddederler. Allah'ın ezelden konuştuğunu (kelam), olmuş ve olacak işleri yazdırdığını, kendilerinin de buna binaen "sultan" olduğunu ileri süren Emevilere göre ise insanlara "zulüm gibi görünen" (şer) işlerin de bu ezeli yazgının gerçekleşmesidir (قضاء). Bu görüşleri temellendirmek için Hz. Ebubekir ve Hz. Ömer

\footnotetext{
42 Muhammed bin Abdurrahman el Ubeydi, et Tezkiretü's Sadiyye fi'l Eş'ari'l Arabiyye, (Beyrut: Dâru'l Kütübi'l İlmiyye, 2001$), 25$.

${ }^{43}$ Bkz. Müslim, Sahih, (Beyrut: Dârü't Kutubi'l İlmiyye, 1991), 1: 1763.

*48. Fetih, 20-22.

${ }^{44}$ Akt. Muhammed Salih es Seyyid, Amr b. Ubeyd ve Ârâuhu el Kelamiyye, (Kahire: Mektebetu Nahdati'ş Şark, 1985$), 96$.

${ }^{45}$ Bkz. İlyas Çelebi, “Hızlan”, Türkiye Diyanet Vakfi İslam Ansiklopedisi, (İstanbul: DTV Yayınları 1998), 17: 419.

${ }^{46}$ Ebu Nuaym, Kitabu'l İmame, (Medine: Mektebetu'l Ulum ve'l Hikem, 1987), 358.

47 İbn Kuteybe, el İmame ve's Siyase, (Beyrut: Dâru'l Edvâ, 1990), 1: 205.
} 
dönemlerinde yasaklanan "Hz. Peygamber'e nispet ederek konuşma" alabildiğine desteklenir. Ancak mevzuat (uydurma rivayet) kitaplarına konu olan ve Hariciler ve Şiilere atfen aktarılan şu ifadeler dönemin ortamını özetler mahiyettedir: "Biz bir araya geldiğimizde bir şeyi "güzel" görmüşsek hadisleştirirdik." 48

Yaşanan siyasi çekişmede "güzelliğin" de ne kadar göreceli olacağı açıktır. Bu durum Emevileri zemmeden rivayetlerin ${ }^{49}$ yanı sıra onları göklere çıkaran rivayetleri50 açıklamaktadır. Ancak siyasi iktidarın belirleyiciliği dikkate alındığında hangilerinin baskın çıkacağı tahmin edilebilir. Rivayet kültürünü alabildiğini esneten bu siyasi programda İsrailiyat da kendisine geniş bir alan bulur. ${ }^{51}$ Yine Hz. Peygambere nispet edilen rivayetlerle "Sultan yeryüzünde Allah'ın gölgesi" 52 addedilir. Buna göre artık iktidarın meşruiyeti, "Allah'ın halifesi" toplumdan (Âdemoğullarından) ya da toplumu temsil eden bir şura yoluyla değil, soydan (Emevi/ Kureyşi/ Arap) olması kesinleşir. İlk defa Muaviye kendisi için "yeryüzünde Allah'ın halifesi" iddiasında bulunur:

$$
\text { الأرض لله و أنا خليفة الله فما أخذتُ فلي، وما تركتُه للناس فبالفضل مني.53 }
$$

“Arz Allah'ın, ben de Allah'ın halifesiyim. Ne almışsam bana aittir. İnsanlara da ne bırakmışsam lütfumdandır."

Bu yazgıcı teoloji ve kavmiyetçi siyaset felsefesine göre doğa olayları gibi insanların yapıp ettikleri de ezeli bir ilahi "konuşma" (kelam) ve "yazg1" neticesidir. Rivayetlere göre Allah'ın ilk yarattı̆̆ "Kalem" olur. "Kalem'e konuşan Allah" (kelamullah) kıyamete kadar olacak olayları yazmasını ister. Ubade bin Samit'in ölüm döşeğinde oğluna şöyle nasihat ettiği aktarılır:

...Başına gelmesi takdir olunan şeyler mutlak başına gelecektir. Şunu da bilmelisin ki sana başına gelmesi takdir olunmayan hiçbir şey de isabet etmeyecektir. Ben Resulullah'ın (s), Allah ilk olarak kalemi yaratmış ve sonra ona yazmasını buyurmuştur. Kalem de kıyamete kadar olacak olan her şeyi yazmıştır dediğini işittim. Ey oğul, eğer bu inanç üzere değilsen öldüğünde cehennemdesin. ${ }^{54}$

"Kalem", kıyamete kadar olacakları Levh-i Mahfuz'a yazar. ${ }^{55}$ Dolayısıla Levh-i Mahfuz imgesi yazg1 öğretisi açısından kilit önem arz eder. Bir rivayete göre Levh-i Mahfuz "beyaz inciden yaratılmış" bir çeşit kitabedir. ${ }^{56}$ Bulunduğu yer ise "Arş'ın sağıdır". Böylesi önceden yazgı ile belirlenme fikrine karşı çıkan muhalifler Allah'ın olayları önceden bilmesinin (el Âlim) başka, insanların fiillerini belirlemek üzere dikte etmesinin (yazdırma) başka anlama geleceğini dile getirirler. ${ }^{57}$ Ancak bu itiraza "Kur'an'dan ayetlerle" cevap verilir. -Rivayete göre- bir adam İbn Abbas'a gelir ve "Kur'an ile ilgili "Biz onu Arapça bir Kur'an kıldık"58 ayetini sorar. İbn Abbas şöyle der: "Allah onu Levh-i Mahfuz'da Arapça yazmıştır. Allah'ın şöyle dediğini duymadın mı?: 'O, Levh-i Mahfuz'da yüzce bir kitaptır'."59

Metafiziğin adeta inkâr edildiği, sadece maddi-cismani bir varlık tasavvuruna dayanan bu söyleme karşı muhalifler ayette Levh-i Mahfuz'un Arapça olduğu anlamına gelmediğini, her şeyden önce Allah'a belli bir "dil" (Arapça) nispet edilemeyeceğini savunurlar. Muhaliflerin bu itirazı da önce "Allah'ın kelam (konuşma) sıfatının”, buna bağlı olarak da konuşmasının bir cüzü olan "Kur'an'ın inkârı" olduğu şeklinde suçlama ile döner. Nihayetinde Kur'an dâhil "semavi kitaplar" Levh-i

\footnotetext{
${ }^{48}$ İbn Cevzi, el Mevzuât, (Medine: Mektebetu's Selefiyye, 1966), 1: 39.

${ }^{49}$ Bkz. Ebu Abdullah Nu'aym bin Hammad, Kitabu'l Fiten, (Kahire: Mektebetu't Tevhîd, 1991), H. No: 422, 164.

${ }^{50}$ Bkz. Nu'aym bin Hammad, Kitabu'l Fiten, H. No: 305, 127.

${ }^{51}$ Bkz. İbn Haldun, Mukaddime, 1: 412.

${ }^{52}$ Belazuri, Ensabu'l Eşraf, (Beyrut: Daru'l Fikr, 1996), 7: 111.

${ }^{53}$ Belazuri, Ensabu'l Eşraf, 5: 27.

${ }^{54}$ Ahmet bin Hanbel, Müsned, (Kahire: Daru'l Hadis, 1995), H No: 22604: 16: 397.

55 İbn Kesir, Tefsîrü'l Kur'âni'l Azîm, (Riyad: Dâru't Tayyibe, 1999), 8: 373.

56 İbn Kesir, Tefsîrü'l Kur'âni'l Azîm, 8: 373.

${ }^{57}$ Bkz. Ebu Hanife, “Fıkhu'l Ekber", İmam-ı A'zam'ın Beş Eseri, trc. Mustafa Öz, (İstanbul: İFAV, 2017), 54.

58 43. Zuhruf, 3.

${ }^{59}$ Suyûti, ed Dürrü'l Mensur fi't Tefsiri'l Me'sur, (Beyrut: Darü'l Fikr, 2011), 7: 365.
} 
Mahfuz'dan "istinsah" edilmiştir. ${ }^{60}$ Buna göre Âdem Cennet'te Arapça konuşmuştur. Yasak meyveyi yiyip âsi olunca Arapça alınır, Süryanice konuşmaya başlar. Ardından tövbe edince tekrar Arapça konuşmaya başlar. ${ }^{61}$ Daha Levh-i Mahfuz aşamasında "Allah Arapça konuştuğuna göre" Âdem'in Arapça konuşması da yadırganacak değildir. Tüm bunlara itiraz eden muhalifler diğer diller gibi Arapçanın da Allah'a değil, yaratılmış insana (Araplara) izafe bir dil olduğunu, insanın ise yaratılmış (mahlûk) olduğunda 1srarlıdır. Bu itiraz da muhaliflere, Kur'an'a "mahlûk" (yaratılmış) deme suçlamasıyla döner. Buna göre "Levh-i Mahfuz yaratılmıştır", ancak oradan gelen Kur'an'a "yaratılmış" denemez! Arapçanın da diğer diller gibi "insan sözü" olduğunda israr eden Mabed el Cüheni (ö. 702), Gaylan ed Dımeşki (ö. 738), Cad bin Dirhem (ö. 742) gibi muhalifler "inanç takibatına" (mihne) tabi tutulur, işkencelerle öldürülürler.

Tüm teolojinin (rivayetlerle) ancak Arapların söz sahibi olabileceği bir geçmişe isnat edilmesi, bu kavmiyetçi siyasetten fayda sağlayan ciddi bir çevrenin (Ehli Hadis) oluşmasına da neden olmuştur. Saray divanında adları kayıtlı bu kimselere, rivayetlere olan "hâkimiyetleri" (ilim) sayesinde yüksek maaşlar verilir. ${ }^{62}$ İlginç olan, rivayetlere atfedilen bu önemin yanı sıra yazılı kültür yerine sözlü (ezber) kültürdeki ısrardır. Hz. Peygamber'in, okuma - yazma öğretme karşılığında Bedir esirlerini serbest bırakması yazılı kültüre verdiği önemi açıkça gösterir. Ancak müesses öğretide onun "vefatına kadar okuma yazma bilmediğinde" israr edilir. Bununla "Kur'an'ın, Ehli Kitaptan öğrenildiğì" iddialarına karşı çıkılmış olur. Oysa felsefesine odaklanıldığında Tevrat'tan o "tanrının seçilmiş halkı" mitine karşı Kur'an'ın tümüyle "ahlak" temelli bir değerler sistemi vaz ettiği, bu haliyle değil Tevrat'tan alınmak, onunla çatıştı̆̆ı açıkça görülür. Buna göre Hz. Peygamber daha önce okuma bilmiyorduysa da, sonra öğrenmesine engel değildir. Bu konudaki 1srar, Hz. Peygamber'e "mucize" atfının ötesinde "ümmi" kültürü mazur, hatta müspet göstermeye varmaktadır. ${ }^{63}$ Üstelik Kur'an'ın yazıya atfettiği öneme rağmen "ilim satırlarda değil, sadırlardadır (göğ̈̈slerdedir)" gibi slogan ifadelerle yazılı kültür adeta küçümsenerek "ümmi - şifahi kültür" yüceltilir. ${ }^{64}$ Bu yazılı kültür karşıtı tavrın açık göstergesi, rivayetlerin derlenmesi sürecinde dahi yazılı bir metin bırakmak için değil, ezberlemek maksatlı yazılmasıdır. Zühri (ö. 742) gibi rivayetleri derlemekle görevlendirilenlerin ezber için yazdıkları rivayetleri daha sonra imha etmeleri bunu göstermektedir. ${ }^{65}$

Oysa beşer hafızası ne kadar güçlü olursa olsun yazılı belge gibi kesin olamaz. Ne kadar kendisinden emin olursa olsun insan zihni -isteyerek ya da istemeyerek- ezberindekilere ekleme ya da çıkarma yapabilir. Sözlü kültürün bu spekülatif doğası gayrı Arap unsurlar için zemini bir kat daha kaygan hale getirir. (Dinî) bilginin tümüyle Arapça (üstelik sözlü) rivayetlere endeksli olduğu bu şartlarda gayrı Arap Müslümanlar en başta dile, kültüre ve tüm bu teolojik tartışmaların kökeninde yatan olaylara yabancıdır. Bu durum bu insanların neden Emevilerin kavmiyetçi politikaları karşısında kolayca "dinen kifayetsiz" ve sürekli imanını ispatlamak durumunda kaldıklarını açıklamaktadır. "Mevali" (azat edilmiş köle, ikinci sınıf vatandaş) denen bu insanların sürekli "iman yetersizliği" ile zan altında baskılandıkları, cizye vermeye, şehir merkezlerinden dışlanıp haraç yükümlüsü kırsalda yaşamaya zorlandıkları açıkça görülmektedir. ${ }^{66}$ Ancak güdülen kavmiyetçi politika nihayetinde isyanları beraberinde getirir, ihtilalle Emevi hanedanı tarihten silinir (750).

\footnotetext{
${ }^{60}$ İbn Âdil, el Lübab fi Ulumi'l Kitab, (Beyrut: Daru'l Kütübi'l İilmiyye, 1998), 20: 257.

${ }^{61}$ Suyûti, ed Dürrü'l Mensur fi't Tefsiri'l Me'sur, 1: 141.

${ }^{6}$ Ör. Bkz. Halit Özkan, "Zühri”, Türkiye Diyanet Vakfi İslam Ansiklopedisi, (İstanbul: TDV Yayınları 2013), 44: 545.

${ }^{63}$ Bkz. M. Suat Mertoğlu, “Ümmi” Türkiye Diyanet Vakfi İslam Ansiklopedisi, (İstanbul: TDV Yayınları 2012), 42: 310.

${ }^{64}$ Bkz. İbnu'l Arîf, Miftâhu's Saâde, (Beyrut: Dar'ul Garb el İslami, 1993), 135.

${ }^{65}$ Bkz. Ahmet Yücel, “Kitabet”, Türkiye Diyanet Vakfi İslam Ansiklopedisi, (Ankara: TDV Yayınları 2002), $26: 82$.

${ }^{66}$ Taberi, Târîhu'r Rusül ve'l Mülûk, (Kahire: Dârü'l Me'ârif, 1967), 6: 381.
} 


\section{Sünnet: Örf mü, Taklit mi?}

Abbasilerle birlikte kadim bir medeniyet merkezi İran coğrafyasında İslamlaşma artar. Fars kültürü Abbasi yönetiminde etkili olur. Bu durum, Emeviler döneminde saray çevresinde öbekleşmiş rivayet camiası açısından avantajlı konumlarının ellerinden çıkması anlamına gelmektedir. Arabi kültürün sahibi olmak üzerinden tüm siyasi-sosyal süreci kontrol edebilen bu çevrelere karşın şimdi böylesi "kavmiyet hassasiyeti" olmayan ${ }^{67}$ bir siyasi akıl söz konusudur. Yeni yönetimin getirdiği açılımlardan rahatsızlık bu çevreyle gerginliğe dönüşür. Geçmiş üzerindeki otoritelerini sürdürebilmek için sosyal hayatı da namaz ve diğer ritüel ibadetler gibi aynen Hz. Peygamber'den alınabilecekmiş gibi tarif eden Ehi Hadis, Sünnete uymayı, "Hz. Peygamber'i birebir taklit" şeklinde gösterir. Böylece Hz. Peygamber'in "oturduğu yere oturmayı"68, "bastığ1 yere basmayı"69, ya da "karpuzun nasıl yediği konusunda rivayet olmadığı için karpuz yememeyi"70 "Sünnete uymak" addeden bir anlayış gelişir. Buna göre insan, rivayetlerle kendisine öğretilmedikçe -bidatlara sapmadan- ne yemeğini yiyebilir, ne de bir bardak su içebilir.

Oysa insanın "fücur ve takva"71 arasındaki farkı dışardan bir "talim" olmadan da bilebileceği (hikmet), bunun hilkatten gelen içkin (mülhem) bir vasıf olduğu, Allah'ın bu "eğitimi" daha Âdem'i yaratırken verdiğ $i^{72}$ açıtı. Ancak Ehli Hadis bunu da reddeder ve hikmet kavramının Sünnet ${ }^{73}$, Sünnetin de "vehbi" olduğu ileri sürülür. Cebrail Hz. Peygamber'e Kur'an'1 getirdiği gibi Sünneti de "vahiy olarak getirmiş" ve (sonradan) öğretmiştir. ${ }^{74}$ Bu durumda -karpuzun nasıl yenileceğinin bilgisi de dâhil - her türlü edim, "Sünnet" (gayrı metluv vahiy) ile bildirilmedikçe bilinemez. İnsanı tümüyle bu dışsal bilgiye endeksleyen Ehi Hadis bu rivayetleri "fıkıh" ile formüle ederek hayatın tamamını kapatan bir ritüeller listesi çıkarır. Ancak hayatın çeşitliliği karşısında nakillerin yetmediği durumlar (içtihat ihtiyacı) kaçınılmazdır. Bu nedenle fıkha, ihtiyaçlara cevap verebilecek şekilde nakilleri esnetmek için İ́ma ve Kıyas ayakları da eklenir (Edille-i Erbaa). Ne var ki bu dört esastan gerçekte sadece bir tanesi içtihat için işlevseldir. Zira ilk iki esas olan Kur'an ve Sünnet "nas" olup "nassın olduğu konuda içtihat kabul edilmez." İ́ma'nın ise pratik karşılığı yoktur. "Konsül" tarzı bir organizasyon (şura) Müslümanlarda hemen hiç olmamıştır. Bir araya gelinip görüşülmeyen bir konuda haliyle "görüş birliği" olduğu iddiası da afakidir. Bu nedenle "Sükût-u İcma" şeklinde bir kavram daha üretilir. ${ }^{75}$ Görüldüğü gibi geriye içtihat için sadece Kıyas kalmaktadır. Kıyasın ise ne kadar subjektif olduğu açıktır; sağlıklı sonuçlar alabilmek için mantık kurallarına (Kelam) dayanmak zorundadır. Aksi halde konunun bir nas ile "benzeştirilmesi” kişiden kişiye değişir. Örneğin adı bile aynı olmasına rağmen günümüz faiz uygulamasının, haram olan "faiz" ile bir ilgisinin olmadığı yaygin bir kabuldür.

İnsanoğlunun en sıradan olaylara ilişkin yetkinliğini (tasarruf hakkını) dahi neredeyse sıfırlayan bu yorum karşısında elbette Sünneti, Hz. Peygamber'in yürüdüğü yol üzerinde gidip gelmek şeklinde değil, değerler eksenli okuyan ve açtığı çığırı sürdürmek, daha uzak mesafeler kat etmek olarak bakan bir görüş de olmuştur. Ehli Rey olarak bilinen bu ekol doğal olarak taklitçi değil tahkikçi bir tavır olarak kendisini gösterir. Gelenek anlayışını, Hz. Peygamber'in ferdiyetinden değil, içinde bulunduğu içtimai hayattan devşiren Ehli Rey bunun için "Örf" kavramını esas alır. ${ }^{76}$ Ehli

\footnotetext{
67 İbn Haldun, Mukaddime, 1: 194.

68 İbn Sa'd, et Tabakatu'l Kübra, (Beyrut: Daru'l Kutubu'l İlmiyye, 1990), 1: 280.

${ }^{69}$ Suyuti, Miftahu'l Cenne, (Kahire: El İdâretu't Trbâatu'l Münîriyye, 1928), 40.

${ }^{70}$ Kastallani, el Mevâhibü'l Ledünniyye, (Beyrut: El Mektebu'l İslami, 2004), 2: 401.

71 91. Şems, 8.

72 2. Bakara, 31.

${ }_{73}$ İbn Hacer Askalani, Silsiletu'z Zeheb, (Beyrut: Daru'1 Marife, 1986), 193.

${ }^{74}$ El Mervezi, es Sünne, (Riyad: Daru'l Asime, 2001), 106.

75 Bkz. İbrahim Kafi Dönmez, “İcmâ” Türkiye Diyanet Vakfi İslâm Ansiklopedisi, (İstanbul TDV Yayınları 2000), $21: 425$.

${ }_{76}$ Bkz. Abdulkadir Muhammed el Kaysi, İctihad ve't Taklid fi'ş Şeriati'l İslamiye ve Ebi Hanife en Numan, (Beyrut: Daru'l Kutubu'l İlmiyye, 2019), 324.
} 
Rey'in ilke edindiği örf tanım gereği bir Nebevi geleneği ifade etmekte olup gerek Kur'an'da ${ }^{77}$ ve gerekse Hz. Peygamber'in pratiğinde doğrudan atıf yapılmış bir kavramdır. Medine sözleşmesinde sıklıkla sorunların çözümünde "örf ve adaletle" yani daha önceden herkesin bildiği ve hoşnut olduğu uygulamaların (بالمعروف)" devamı öngörülür.78 Buna göre "örf" belli bir zamanda konmuş bir yasal düzenlemeden öte bu yasayı da belirleyen, toplumun bir arada yaşama konusundaki norm niteliği kazanmış tarihi birikimi, teamülleri, "meleke" halini almış ve gerçekten adilane uygulamalarıdır. Bir nassa dayamayan bu uygulamalar fitri olup "Müslümanın güzel gördüğü Allah indinde de güzeldir."79 Hz. Peygamber'in hayatı boyunca yaptıkları düşünüldüğünde sonuç olarak İslam'ın, içinde yaşanılan toplumdaki iyilikleri (maruf-معروف) desteklemek, güçlendirmek ve kötülükleri (münker- منكر) mümkün olduğunca ortadan kaldırmak olduğu görülür. ${ }^{80}$ Kötü bir âdete itirazla Hz. Peygamber'e gelen bir kadının isteğinin Kur'an tarafından teyidi bunun açık bir göstergesidir. ${ }^{81}$ Anlaşılacağı üzer Hz. Peygamberin tebliğinde geçmişe "format atma" değil, olumsuzluklarla mücadele ve var olan güzel (حسن) uygulamaları da güçlendirerek devam ettirme, "1slahçı" bir tavır esastır. Buna göre lanetli bir "beşer hükmü" imgesinin ne kadar yanlış olduğu, "cahiliye" derken dahi İslam’ın kastının geçmişi inkâr olmadığı açıkça görülmektedir. Kur'an'da Hz. Peygamber'in tasarruflarını ifade etmek anlamında "Sünnet" kavramı geçmez, ama "örf" kavramı kesinlikle Nebevi Sünneti de içine alan Kur'ani bir kavramıdır. İnsanın, "fücur ve takva” arasında hakikati kavramaya yetkinliği ${ }^{82}$ teyit edilerek gelenek (örf) inşa hakkı teslim edilir.

\section{Ehli Rey, Ehli Hadis ve Siyaset}

Bu örf anlayışı Ebu Hanife'nin (ö. 767) "istihsan" (استحسان) kavramının da temelidir.83 Buna göre tüm diğer toplumsal normlar gibi dinî naslar da "hikmetinden sual olunmaz" insan ötesi buyruklar değil, uhrevi kurtuluşun da yolu olan toplumda adalet ve maslahata matuftur. Nitekim onun örf temelli usulünde de Emevi siyasetinin mağduru gayrı Arap Müslümanların konumlarının güçlendirildiği açıtır. ${ }^{84} 750$ yılında Emeviler yıkılıp Abbasiler iş başına geçince dayandığı toplumsal taban gereği rivayet kültürüne itibar etmeyen yeni yönetim tarafından da bu usul kabul görür. Onun da ilk başlarda Abbasi yönetimini desteklediği, ancak Abbasilerin Ehli Beyt karşıtı politikaları nedeniyle ${ }^{85}$ daha sonra kendisine getirilen kadılık görevini dahi "ölümüne" geri çevirdiği görülmektedir. Abbasi sarayındaki üst düzey bilginlerden İbn Mukaffa'nın (ö. 759) kaydettiklerinden anlaşıldığı üzere Ehli Rey'in bu dinamik gelenek anlayışına karşın geçmiş ile ilişkiyi, kendilerinin söz sahibi olduğu rivayetler üzerinden tanımlayan Ehi Hadis, siyaset kurumuna ciddi sorunlar çıkarmaktadır. Bu çevrelerin "Sünnet'e ters davranmakla" suçladıkları insanların hayatlarına bile kast edecek kadar cüretkâr oldukları anlaşılmaktadır:

...Sünnete sarılma iddiasındakilere gelince, bunlar da Sünnet olmayan şeyleri “Sünnet” yapmaktadırlar. Bu durum öyle boyutlara varmaktadır ki, Sünnet olduğu iddiasıyla yok yerden insanların kanını dökmeye kadar gitmektedir. Yaptıkları kendilerine sorulduğunda ise Hz. Peygamber ve Râşit Halifeler döneminde böyle kan döküldüğünü söyleyememekteler. Onlara, "bu iddia ettiğiniz Sünnete göre kimin kan akıtılmış?" diye sorulduğunda, Abdülmelik b. Mervan gibi bazı [Emevi] yöneticileri gösterirler. Bunlar gerçekte sadece kendi kabulleriyle hareket etmekteler... Bu görüşlerinde yalnız kalmalarını bile hiçbir

\footnotetext{
77 “Bağışlayıcı ol, Örfle buyur.. (وامر بالعرف)" 7. A'raf, 199.

78 İbn Hişam, es Siretü'n Nebeviyye, 2: 143.

${ }^{79}$ Vehbi Süleyman Gavci, Ebu Hanife Numan, (Dımaşk: Daru'l Kalem, 1999), 141.

80 3. Âli İmran, 104.

81 58. Mücadele, 1.

82 91. Şems, 8.

${ }^{83}$ Bkz. Gavci, Ebu Hanife Numan, 140.

${ }^{84}$ Bkz. Muhammed Ebu Zehra, Ebu Hanife, (Kahire: Daru'l Fikr el Arabi, 1955), 271.

${ }^{85}$ Bkz. Mehmet Ali Büyükkara, İmamet Mücadelesi ve Haşimoğulları, (İstanbul: Rağbet Yay., 1999), 29.
} 
şekilde yadırgamaz, tuhaflık hissetmezler. Kitap ve Sünnete dayanmadığını; kendi görüşü olduğunu bildikleri halde israr ederler. ${ }^{86}$

Yönetimde rivayetlere dayalı "uzman görüşlerin" (Ehli Hadis) dikkate alınmaması ve bunun yerine insani inisiyatifle hareket edilmesi yine bir "beşer aklı" söylemini aralar. Siyaset kurumunun her türlü tasarrufunu rivayetlere dayandırması gerektiği, rivayetle dayanmayan her tasarrufun "zındıklık" anlamına geleceği iddiasında bulunulur. ${ }^{87} \mathrm{Bu}$ maksatla Kur'an'daki onca akıl vurgusu görmezden gelinerek "akıl" kavramı "heva" ile özdeşleştirilir. Böylece Abbasi yönetimi "Hz. Peygamberin Sünneti" addedilen rivayetler yerine beşer aklını esas almak, "beşerin heva ve hevesine uymakla" suçlanır. Bu suçlamaların, iktidarın meşruiyetini sorgulayarak "Yaratıcıya isyanda yaratılana itaat yoktur" şeklinde halkı kışkırtmaya dahi vardığ188 görülmektedir:

Allah'tan gelen bu dinin, Hz. Peygamberin gönderilişinden kıyamete kadar gelecek insanlar için geçerli hükümler, düşünceler, emirler ve insanların karşılaşacağı bütün işlerde bir harfini bile feda etmeden, sadece "azimet" gösterip uymak durumunda oldukları hükümlerin tümünü ifade ettiği kabul edilecek olsaydı, o zaman bu insanlara takatlerinin üzerinde bir sorumluluk yüklenmiş olurdu. Kulaklarının duyma, akıllarının anlama kabiliyetini aşan şeyler onlara gönderilmiş olurdu. Sonuç olarak Allah'ın nimet olarak verdiği akıl ve zekâları, karşılaştıkları şeyden dolayı şaşkınlığa düşerdi. Bu durumda akıl ve idrak, hiçbir konuda kullanılmayan, işlevsiz bir şey olarak anlamsız kalırdı. ${ }^{89}$

İbn Mukaffa'nın dediği gibi insan aklını âtıl bırakan bu din tasavvurunun aslında gerçek hayatta da bir karşılığ1 yoktur. Nihayetinde rivayet kültürü de akla dayanmak durumundadır. Bir rivayetin taşıyıcısının (ravi) güvenilirliğini tespit ederken de akıl ile hareket edilmek durumundadır. Nitekim farklı siyasi tercihlerin (akılların) aynı ravi hakkında birbirine zıt görüşler ileri sürdüğüne ilişkin pek çok örnek verilebilir. ${ }^{90} \mathrm{~Hz}$. Peygamber dönemi muamelatı, bir daha insan aklını kullanmaya gerek kalmayacak kadar tüm zamanları karşılayacak şekilde görmek, geçmişe gerçekliği olmayan bir sorumluluk yüklemektir. Hz. Peygamberin vefat etmeden önce yapabilecekken yapmadığı ya da "yapın" diyebilecekken demediği pek çok şey bizzat sahabe döneminde yapılmıştır. -İmam Eş'ari'nin de vurguladığı gibi Hz. Peygamber'in vefatıyla söylenecek her sözün bittiği, bundan sonra söylenecek ya da yapılacak her şeyin "bidat" olduğu iddias1 ${ }^{91}$ doğru olsaydı;

- En başta Kur'an'ın kitaplaşması mümkün olmazdı; Hz. Peygamber bu yönde bir şey söylememişti.

- Tarihlendirme mümkün olmazdı; "Hicri Tarih" pratik hayatın ihtiyaçlarına binaen Hz. Ömer döneminde kabul edilmiştir.

- Hadis kitaplarının hiçbiri olmazdı; Hz. Peygamberin Kur'an dışında bir şey yazılmamasını söylediği mervidir.

- Arap yazısının gelişmesi mümkün olmazdı; Arap alfabesi özellikle Kur'an'ın kıraati ile ilgili sorunlar üzere geliştirilmiştir.

- Devlet düzeninden söz edilemezdi; divan, vezirlik, ikta gibi çoğu düzenleme başta İran, başka memleketlerin tecrübelerinden alınmıştır.

- Para basılmazdı; Müslümanlar Abdülmelik zamanına kadar Rumların (Dinar) ve Farsların (Dirhem) paralarını kullanmıştır.

Nitekim hayatın ihtiyaçları karşısında iç çelişkilere düşen nakilcilik sorunu felsefi temellerinden görmek yerine kelimeleri kâh bölüp kâh birleştirerek yeni kavramlar ihdas etme yoluyla soyut dilin kaypaklığına sığınacaktır. Yeni olan her şeye bidat denip hayatın doğal akışı tıkanınca açmak için yeni

\footnotetext{
86 İbn Mukaffa, “Risaletü's Sahabe”, Âsâru İbni'l Mukaffa, (Beyrut: Dâru'l Kütübi'l İlmiyye, 1989), 317.

${ }^{87}$ Bkz. İbn Kuteybe, el İmame ve's Siyase, 2: 231.

88 İbn Mukaffa, "Risaletü's Sahabe", 312.

89 İbn Mukaffa, "Risaletü's Sahabe", 313.

${ }^{90}$ Bkz. Nihat Dalgın, "İbn Lehîa” Türkiye Diyanet Vakfı İslam Ansiklopedisi, (İstanbul: TDV Yayınları 1999), $20: 158$.

${ }^{91}$ Eş'ari, İstihsânü'l Havz fì 'ìlmi'l Kelâm, 2.
} 
kavramlara ihtiyaç duyulacak; "bidat-1 hasene", "bidat-1 seyyie" ayrımına gidilecektir.92 "Vahiy" kavramı yetmeyecek, "vahyi metluv"-“vahyi gayrı metluv" türetilecektir. "Kelam” yetmeyecek, "Kelam-1 Nefsi"-"Kelamı Lafzi" türeyecektir, hatta "cehennem" yetmeyecek "büyük cehennem", "küçük cehennem" türetilecektir. ${ }^{93}$ Siyaset kurumu ise Ehli Rey'in açtığı çığırdan kendi meşruiyet temellerini oluşturur ve yoluna devam eder.

Genel olarak Abbasiler kuşatıcı bir politika benimsemişlerse de taht değişimlerinde yaşanan ihtilaflar Ehli Hadis için sürece müdahale fırsat yaratır. Bu ihtilaflarda eski hizip ve kavmiyet alışkanlıklarını besleyen kavgalar yaşanır. Bu kavgalardan biri özellikle halife Harun Reşit'in (ö. 809) Arap asıllı eşinden oğlu Emin ile Fars asıllı eşinden oğlu Me'mun arasında görülür. Kendisini veliahtlık sıralamasında dışarıda bırakmak isteyen Emin'e karşı harekete geçen Me'mun Arap olmayan Müslümanların desteğiyle halife olur. Merkezde Me'mun gayrı Arap kitleden çok yazgıcı teolojiye karşı olan bilginlerin desteğini yanında görebilmektedir ki bunlar da genel olarak gayrı Arap unsurlardır. Me'mun'un hilafeti İslam tarihinde tam bir "aydınlanma" rüzgârı estirir. Gümümüzde Müslümanların bilime katkısı bakımından örnek gösterdiği çalışmaların çoğu $\mathrm{Me}^{\prime}$ mun döneminde ya da onun attığ ${ }_{1}$ temeller üzerinde gerçekleşmiştir. ${ }^{94}$ Fakat Ehli Hadis, Me'mun'un iktidarının meşruiyetini tanımamakta karalıdır. Rivayetlerin esas alınmamasını "beşer aklı" ve Sünnet karşıtlı̆̆ olarak yaftalayan Ehli Hadis ile Me'mun'u destekleyen Mutezile arasında sıkı bir mücadele yaşanır. Emevilerin yazgı teolojisi Me'mun karşıtlığının ifadesi haline gelir. Bu dönem ismi öne çıkan Ahmed bin Hanbel, yazg1 öğretisinin takipçisi olur. ${ }^{95}$ Muhalefetini, Emeviler siyasetinin uzantıs ${ }^{96}$ ve yazg1 fikrinin dayanağı "Kelamullah" kavramı üzerinden yürüten İ̉n Hanbel, Allah'tan insan gibi "ses" (Arapça) sadır olmasının yadırganamaması gerektiğini savunur ${ }^{97}$ ve buna uygun olarak oldukça "somut" (mücessem) bir tanrı tasavvuru vaz eder. Bunu yaparken Allah'a "cisim" olma (sınır, hacim, mekân) atfettiği eleştirilerine de Allah'ın zaten her yerde olmadığını, yedinci kat semada istiva durumunda olduğunu söyler:

Müslümanlar, Rablerinden bir şeyin bulunmadığg çok yer biliyor. "Ne gibi yerler" derler. Onlara şöyle deriz: "Sizin iç organlarınız, bağırsaklarınız, domuzların bağırsakları, işkembeler, pislik yerleri, evet bütün bu gibi yerlerde Rab Teala'dan bir şey yoktur. Rabbimiz gökte olduğunu haber vererek şöyle buyurmuştur, "Gökte olantn sizi yere geçirmeyeceğinden emin misiniz..."

\section{Bir Uzlaşı Arayışı Olarak Eş'arilik}

Kaynaklarda çoğunlukla tartışmanın sosyo-politik zemini aktarılmadığı için hala anlaşılmasında güçlük çekilen “Halku'1 Kur'an” meselesinin arkasında görüldüğü üzere gayet anlaşılır siyasi nedenler vardır. Buna göre Ahmed bin Hanbel temsil ettiği kitle açısından sözlerinin tutarlılığından çok örgütleyici rolüyle önem arz etmiştir. Me'mun'un, Bizans'a karşı çıktığı bir sefer nedeniyle Tarsus'ta bulunduğu bir sırada büyüyen tartışmalar sonucu İbn Hanbel, Bağdat Valisi İshak b. İbrahim tarafından mahkûm edilir. Olayları haber alan Me'mun, İbn Hanvbel ile bizzat görüşmek ister. Yola çıkılır, ancak heyet yoldayken Me'mun'un ölüm haberi gelir (833). ${ }^{99}$ Böylece tekrar Bağdat'a dönülür ve yeni halife Mutasım döneminde Ahmed b. Hanbel iki sene hapis tutulur, sonra serbest bırakilır.

\footnotetext{
92 Bkz. Rahmi Yarman, “Bidat”, Türkiye Diyanet Vakfi İslam Ansiklopedisi, (İstanbul: TDV Yayınları 1992), 6: 129.

${ }^{93}$ Bkz. El Hereri, Tefsiru'l Hadâiku'r Ruh ve er Reyhân, (Beyrut: Daru't Turuk, 2001), 398.

${ }^{94}$ Bkz. Fuat Sezgin, Tanınmayan Büyük Çă̆, (İstanbul: Timaş Yay., 2010), 29.

${ }_{95}$ Bkz. İbn Kesir, Büyük İslam Tarihi, trc. Mehmet Keskin, (İstanbul: Çağrı Yayınları, 1994), 8: 378.

${ }_{96}$ Bkz. Muhyettin İğde, Siyasi-İtikadi Bir Mezhep Olarak Hanbeliliğin Teşekkül Süreci, (İstanbul: MÜ İlahiyat Fakültesi Vakfı Yayınlar1-ïFAV), 49.

${ }_{97}$ Ahmed bin Hanbel, er Red ale'l Cehmiyye ve'z Zenâdıka, (Riyad: Dâru's Sebât, 2003), 137.

${ }^{98}$ Ahmed bin Hanbel, er Red ale'l Cehmiyye ve'z Zenâdıka, 144.

99 İbnü'l Esir, el Kâmil fi't Tarih, (Beyrut: Daru'l Kutubu'l İlmiyye, 1987), 6: 6.
} 
Mütevekkil (ö. 861) dönemine gelindiğinde yeni bir durum ortaya çıar. Özellikle Türklerin büyük kitleler halinde İslam'a girmesi ve başta ordu kademeleri olmak üzere merkezde artan nüfuzları siyasi dengeleri sarsar. Aslında Mütevekkil'in annesi de Fars asıllıdır. Ancak halife, Türklerin artan nüfuzunu dengelemek için merkezde Arapların desteğine ihtiyaç duyar. Bu maksatla merkezi Şam'a taşımaya kalkışsa da başarısız olur. ${ }^{100}$ Fakat bu politikayla resmi din görüşü de tersyüz olur ve Mutezile taraftarları tümden ötelenirken Ehli Hadis yeniden el üstünde tutulur. Yaşananlardan sonra Ahmed b. Hanbel bir "kahraman" olarak yönetim kademesinde itibar görür. Bundan böyle siyaset kurumunun Ehli Rey'den gelen Örf öğretisi, Ehli Hadis ile problem yaşamayan bir siyasi iktidar olduğunda sorun olmazken Ehli Hadis ile problemli yönetimler söz konusu olduğunda her seferinde bir "beşerin hükmü" tartışması nükseder.

Ancak Ehli Hadis'in dar kalıplarının yol açttğı toplumsal sorunlar bir yana, mücessem tanrı tasavvurunun teorik açmazı diğer âlimleri tarafından da görülür. Bu ortamda adeta bir uzlaşı arayışı olarak İmam Eş'ari, Mutezile'den Ehli Hadis safına geçer. Kitaplarında doğrudan Ahmed bin Hanbel'e hürmet takdimleriyle "sözlerini kabul ederiz" diye vurgular. ${ }^{101}$ Ancak Eş'ari eli boş gitmez; Kelami düşüncenin önemini bizzat Ehli Hadis toplumuna içerden anlatmaya çalışır. ${ }^{102}$ Allah'a Arapça nispet etmenin, İslam'ın tevhit öğretisiyle bağdaştıracak bir tarafı olmadığının, Allah'a cisim denemeyeceğinin ${ }^{103}$ gayet farkında olan Eş'ari sorunun temelindeki politik süreci geride bırakarak teorik temelde bir anlayış geliştirmeye çalışır. Ancak tüm bu "esnetme" çabalarındaki niyeti gayet iyi gören Hanbeliler onu hiç de hoş karşılamaz. Yaşadığı saldırlar karşısında Eş'ari de üslubunu sertleştirmek zorunda kalır. Kelami düşüncenin önemini vurguladığı "İstihzanu'l Havuz" risalesinde Kelamcıları dalaletle suçlayanların kendileri istedikleri gibi konuştuklarını, kendi lehlerine söyleyecek söz bulamayınca da "biz kelamdan nehiy olunduk" diyerek "nasçı" kesildiklerine işaret eder:

Din konusunda araştırma ve düşünme kendilerine ağır gelen bazı kimseler cehaleti kendilerine sermaye edindiler. Kendilerinin kolaya kaçarak taklide meyletmeleri yetmediği gibi dinin temel konularına kafa yoranları da sapkınlıkla itham ettiler... ${ }^{104}$

Bu ayrışmayla, hocalarının açtığı çığırı geliştiren Eş'ari bilginler kökleri daha önce İbn Küllab (ö. 854), İmam Buhari (ö. 869) ve başından beri Ehli Hadis ile sorunlu bir gelenekten gelen Maturidi (ö. 944) gibi bilginlere giden bir ayrımla "Allah'ın konuşması" (Kelamullah) ikiye ayırırlar. Buna göre Kur'an'ın nüzulünden önceki hali "kadim" olup "Kelam-1 Nefsi" denir. Hz. Peygamber'e gelmiş ve onun tarafından ifade edilmiş telaffuzu ise "mahlûk" (Arapça) olup "Kelam-1 Lafzi" denir. ${ }^{105}$ Bu çıkış karşısında Ehli Hadis'in diğer âlimlere olduğu gibi Eş'ariler'e karşı da şiddeti kimi zaman büyük toplumsal olayların yaşanmasına neden olsa da sıfatlar konusundaki ayrışma bir yandan da Eş'arilik ile Maveraünnehir bölgesinden gelen Maturidilik arasında bir yakınlaşmayı getirir. Buna karşın Hanbelilik kendi görüşünde en ufak bir tashihe gitmemede israrlıdır. Bu tavır, toplumda da huzursuzluklara neden olur. Özellikle 10. yy.da Bağdat'ta başını Berbehari'nin (ö. 941) çektiği Hanbeli grup Hacca giden Şiileri darp edip öldürür, çalgı sesi gelen evleri basıp müzik aletlerini kırarlar. Sonunda dönemin halifesi Razi Billah bir ferman yayınlayarak tutuklanmaları talimatı verir, Berbehari kaçıp saklanır. ${ }^{106} \mathrm{Bu}$ arada tarih sahnesine çıkan Selçukluların da başta vezir Kunduri (ö. 1064) gibi etkili isimler nedeniyle Mutezili düşünceye yakın olduğu görülmektedir. Ancak Nizamülmülk (ö. 1092) ile birlikte Eş'arilik büyük bir himaye bulur. Böylece merkezde Hanbeli damarı köreltmenin zamanı gelmiştir. Bu yönde önemli bir adım Gazali'den gelir. Hanbeliliğe göre "Allah'ın konuştuğu dil" olan Arapça hakkında Gazali şöyle der:

\footnotetext{
${ }^{100}$ Fatih Güzel, “Abbâsî Halifesi Mütevekkil'in Türk Nüfuzunu Sonlandırma Çabaları”, KAREFAD, 4/2 (2016), 117.

${ }_{101}$ Eş'ari, El İbane, (Dımaşk: Daru'l Beyan, 1990), 43.

102 El Hay Ebu Amr, et Temyiz, (Kuveyt: Garas li'n Neşr, 2007), 10.

${ }^{103}$ Eş'ari, el Lüma, (Beyrut: Daru'l Kutubu'l İlmiyye, 1971), 18.

${ }^{104}$ Eş'ari, Risaletu İstihsânü'l Havz fì 'İlmi'l Kelâm, (Haydarabad: İdaretu'l Maarif el Osmaniyye, 1979), 2.

${ }^{105}$ Eş'ari, Makalatu'l İslamiyyin, (Beyrut: el Mektebetü'l Asriyye, 1990), 2: 257.

106 Ahmet S. Kilavuz, “Berbehari”, Türkiye Diyanet Vakfı İslam Ansiklopedisi, (İstanbul: TDV Yayınları 1992), 5: 476.
} 
Diğer bir fırka da nahiv, lügat, garîbi lügat ve şiirle meşgul olarak bunlara aldandılar. Bunlarla uğraşmakla affedileceklerini sandılar, kendilerini bu ümmetin âlimlerinden zannettiler. Zîra "dinin ayakta durması, kitab ve sünnet ile bunların da ayakta durabilmesi lügat ve nahiv iledir" dediler ve ömürlerini nahvin inceliklerinde, şiir san'atında ve garîb lügatlerde tükettiler. Bunlar, ömürlerini yazı, sanat ve tekniği ile tüketip, ilimlerin mutlak surette yazı ile temin edileceğini, bu bakımdan yazının öğrenilip tashihinin zaruri olduğunu sananlar gibidir. Eğer biraz düşünse, okunaklı yazı yazmanın yetişeceğini, diğerinin fazlalık olduğunu anlardı. Edebiyatçı da eğer düşünseydi, Arap edebiyatının diğger lisan edebiyatından farklı olmadığını, Arap dili ve edebiyatı ile uğraşmanın, herhangi bir dilin edebiyatından farkl bir hususiyet taşımayacă̆ııı anlardı. Aradaki fark, Kur'an ve Sünnetin Arapça olmasındadır. ${ }^{107}$

Görüldüğü gibi tüm eleştiriler yine de doğrudan isim verilmeden diplomatik bir dille yapılmaktadır. Yine Gazali "Hakikati arayan gruplar" tasnifinde dört grup olarak Kelamcıları, Bâtınileri, Felsefecileri ve Sufileri sıralar ve kendisi tercihini Sufilerden yana koyar. ${ }^{108}$ Ancak dikkat edilirse bu guruplar arsında Ehli Hadis ya da Hanbelileri tarif eden bir kategori yoktur. Gazali, tasnif dışı bırakarak tüm eleştirilerine rağmen aslında Ehli Hadis'i korumuştur. Ancak istisna da olsa kimi zaman üslubun sertleştiği de olmaktadır. Maturidi bilginlerden Ömer Nesefi'nin (ö. 1142) kitabını şerh eden Eş'ari âlim Taftazani (ö. 1390) şöyle der:

Ömer Nesefi metinde "el-Kur'an kelamullah" demek suretiyle önce "Kur'an'1" zikrettikten sonra peşinden, "kelamullah" tabirini getirdi. Zira kelam âlimleri, "Allah Teâlâ'nın kelamı olan Kur'an gayrı mahlûktur denilir ama kadim ve ezeli olan harf ve seslerden mürekkeptir fikri akla gelmesin diye Kur'an gayrı mahlûktur denilmez" demişlerdir. Nitekim cahillikleri veya inatçlıkları sebebiyle Hanbeliler bu kanaatle harf ve seslerin kadim olduğu fikrine sahip olmuşlardır. (Onun için Kur'an mahlûk değildir demektense) Allah'ın kelamı olan Kur'an mahlûk değildir demek daha uygun olmuştur. ${ }^{109}$

Sonuç olarak Allah'a ilişkin Kur'an'daki, "haberi sıfatlar" olarak adlandırılan (vecih, yed, istiva, nüzul vb.) ifadeler mecaz kabul edilerek daha "soyut" bir tanrı tasavvuru kabul görür. Tüm bu yaşananlar için nihayet bir "dönemlendirmeye" gidilerek "yumuşak geçiş" sağlanacaktır: Selef - Halef. ${ }^{110}$ Buna göre haberi sıfatları tevil etmeyenler "Selef", tevil edenler (Eş'ari ve sonrası) Halef olarak adlandırılacaktır. ${ }^{111}$ Yaşananlardan, Hanbelilik konusunda Eş'arilik ve Gazali'nin tavrının, Batınilik gibi tehditlere karşı merkezi konsolide etme; bir denge ve uzlaşı arayışı olarak görülmelidir. Fakat onların uzattığı el karşılık görmediği gibi meseleler daha bir karmaşık hale gelmiştir. Bu karışıklıkta asıl mücessimeye yöneltilmesi gereken eleştirileri paratoner gibi üzerlerine çeken bu iki dâhiye ilişkin açmaz meselenin özünü teşkil etmektedir. Dinî bilginin temelinde bir yandan aklı dışardan bırakan Edille-i Erbaa (Ehli Hadis) kabul edilir, bir yandan da bilginin kaynağını "akıl, duyular, doğru haber" şeklinde sıralayan Kelami düşünceden, mantıktan vazgeçilmez. Öte yandan tüm bu tartışmalara paralel olarak siyasi akıl bir pragmatizmle Ehli Rey yoldan yürümeye devam eder.

\section{8. İbn Teymiyye: Allah'ın Hükmü Versus Beşerin Hükümü}

Eş'ari ve Gazali'nin kurduğu dengenin bozulması çok sürmez. 14. yy.a gelindiğinde Moğol istilası ile karşılaşan İslam coğrafyasında Hanbeliliğin kendisini göstermesi için yeni bir ortam oluşur. Bilindiği üzere özellikle Gazan Han'dan (ö. 1304) itibaren Moğol İlhanlı devletinde İslam benimsense de bir yandan da Cengiz yasası "Yasak" (Moğol örfü) uygulanmaya devam edilir. Bu şartlarda ismi öne çıkan İbn Teymiyye (ö. 1328), Moğol karşıtı siyasetin teolojik temellerini oluşturur. Kur'an'daki, "Allah'ın indirdikleri ile hükmetmeyenler kâfirlerdir"112 ayetinden hareketle, kendi örflerinden

\footnotetext{
107 Gazzali, İhyâu Ulûmi'd Dîn, trc. Ahmet Serdaroğlu, (İstanbul: Bedir Yayınları, 2002), 3: 851.

108 Gazali, El Munkızu min ed Dalal, trc. Hilmi Güngör, (Ankara: MEB Yayınları, 1960), 22.

109 Taftazani, Şerhu'l Akâid, trc. Süleyman Uludağ, (İstanbul: Dergâh Yayınları, 1991), 169.

110 Bkz. Sâbir Abduh Eba Zeyd, Minhâcü Ehli's Sünne, (İskenderiyye: Dârü'l-Vefâ, 2005), 158.

111 Bkz. Şehristani, Milel ve Nihal, trc. Mustafa Öz, (İstanbul: Litera Yayınları, 2011), 91-92.

112 5. Maide, 44.
} 
(Cengiz yasası) tümden vazgeçmeyen Moğollara karşı cihat fetvası verir. ${ }^{113}$ Ehli Hadis söylemin devamı "beşer hükmü" Cengiz yasasına karşı "Allah'ın hükmü" şeklindeki karşıtlık, Müslüman hukukunun ilahiliğine/gökselliğine vurguyu arttırır. Böylece İbn Teymiyye'nin eserlerinde yoğun şekilde Hanbeliliğin "Kur'an'ın kıdemi" konuşu yeniden işlenir, Kur'an'ın Arapça "ses ve harfleriyle Allah'tan olduğu" savını tekrarlama ihtiyacı duyulur. Tüm bunlara binaen İbn Teymiyye de haberi sıfatlar konusunda oldukça mücessem; yedinci kat gökte istiva etmiş bir tanr fikri vaz eder. ${ }^{114}$ Böylece "dünya merkezli evren" fikrinin bir kez daha altı çizilmiş olur. O da bu görüşü sahabe, tabiin ve tebe-i tabiin; yani "Selef" görüşü olarak geneller ve kendisini de onlara nispet ederken İmam Eş'ari gibi aksi görüştekileri bidatçılıkla itham eder. Ancak başta Eş'arilerle girdiği bu zitlaşma nedeniyle suçlu bulunup hapsedilir. Sonuç olarak İbn Teymiyye'nin görüşleri kendi döneminde çok da revaç bulmaz ve Moğollardan sonra normalleşen şartlarda "örf" siyaset kurumunun tasarrufları için kullanılan bir kavram olarak "Siyaset-i Şeriyye", "Örfi Sultani", "Siyaseti Sultani" gibi adlarla hukuk sisteminde yerini alır. Konu Osmanlı hukuk düzeninde de şöyle ifadesini bulacaktır:

Nizam-ı âlem için akla dayanarak hükümdarın koyduğu nizama Siyaset-i Sultani ve Yasag-ı Padişahi derler ki urefamızca ona örf derler. ${ }^{115}$

Teorik meşruiyet temelleri üzerinde çok fazla durulmasa da bu "akılcı" (Selefilik açısından beşeri) tutum Osmanlı hukuk sistemindeki esnekliği de açıklamaktadır. Öyle ki açık naslarda bile farklı uygulamalara gidilebildiği görülmektedir. Örneğin Kanuni Süleyman dönemi Osmanlı hukuk metninde şöyle denmektedir:

$$
\begin{aligned}
& \text { بر مسلمان زنا قلسه شرعله ثابت اولسه وزنا قيلان اولو اولسه بيك اقجه يادها زيادهيه كوجى يترسه اوج يوز اقجه جريمه النه و اوسط الحال اولوب التى يوز اقجهيه } \\
& \text { مالك اولسه ايكى يوز اقجه جريمه النه... }
\end{aligned}
$$

Bir Müslüman zina kılsa, şer'ile sabit olsa ve zina kılan evli olsa, bin Akçe ya da ziyadeye gücü yetse, üç yüz Akçe cerime alına. Ve evsâtu'l hal olup altı yüz Akçeye mâlik olsa iki yüz Akçe alına...

Böylece tarih boyunca Müslüman ülkeleri biryandan örfi hukuk şeklinde canlı hayatın taleplerine cevap verirken bir yandan da "içtihat kapısı kapandı" sözleri terennüm edilegelir. Ancak Osmanlı'da da Kadızadeliler benzeri İbn Teymiyyeci akımların ${ }^{117}$ yol açtıkları onca soruna rağmen kontrollü de olsa varlıklarını sürdürmelerine göz yumulduğu açıtır. Muhtemelen bunda da yine formal olanı aşırı küçümseyen Bâtıni akımlar ve bu baskı unsurunun olmadığı ortamda serbestliğin sistemi çökertecek sonuçlara gidebileceği endişesidir. Nihayetinde saray her ne kadar tutucu çevreyle ihtilaf yaşasa da iktidarının meşruiyetini aynı "eoren modelinde" bulmaktadır. Topkapı Sarayı'nın ana giriş kapısı olan Bab-1 Humayun'un üzerindeki kitabe bu durum şöyle özetlidir:

$$
\begin{aligned}
& \text { هذه قلعة مباركة أسس بنيانها على تأييد من الله ورضوان، ورصص أركانها بتشييد من الأمن والأمان بأمر سلطان البرّين وخاقان البحرين ظلّ الله في الثقلين عون الله }
\end{aligned}
$$

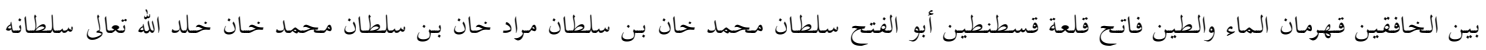

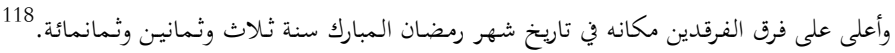

Bu mübarek bir kaledir ki Allah'ın te'yid ve rızasıyla kuruldu ve erkânı emn-ü emânıyla kuvvet buldu. Karaların sultanı denizlerin hakanı, iki âlemde (sakaleyn) Allah'ın gölgesi, doğuda ve batıda Allah'ın yardımı, denizlerin ve karaların kahramanı, Kostantin Kalesi'nin fatihi Sultan Mehmed Han oğlu Sultan Murad Han oğlu Ebu'l Feth Sultan Mehmed Han'ın Allahu Teâlâ saltanatını daim eylesin ve mevkiini kuzey yıldızlarının fevkinde etsin. Sekiz yüz seksen üç senesi Ramazanü'l-Mübarek ayında inşa edildi.

\footnotetext{
${ }_{113}$ Bkz. U. Töre Sivrioğlu, “İbn Teymiyye'nin Siyaset, Hukuk ve İktisat Teorisi”, Yönetim ve Ekonomi Araştırmaları Dergisi, (2013), 20: 97.

114 İbn Teymiyye, Mecmu'u'l Fetava, (El Mansure: Darul Vefa, 2005), 12: 39.

${ }^{115}$ Akt. Halil İnalcık, Osmanlı'da Devlet, Hukuk, Adalet, (İstanbul: Eren Yayınları, 2005), 27.

116 Bkz. Kanunname-i Âl-i Osman, "Bâb-1 Evvel”, (İstanbul: Tarih-i Osmani Encümeni Mecmuasının İlavesi, Ahmed İhsan Şürekası Matbaacılık Osmanlı Şirketi, 1329), 1.

${ }_{117}$ Bkz. Semiramis Çavuşoğlu, “Kadızâdeliler”, Türkiye Diyanet Vakfı İslam Ansiklopedisi, (İstanbul: TDV Yayınları 2001), $24: 100$.

${ }^{118}$ Ekrem Hakkı Ayverdi, Osmanlı Mimarisinde Fatih Devri, (İstanbul: Baha Mtb, 1974), 4: 700
} 
Buradaki evren modeli (ve siyaset felsefesi) bilindiği üzere dünyanın geri kalanında oluğu gibi daha önce işaret edildiği üzere Hıristiyan Avrupa'da da geçerlidir. Hatta İslam dünyasındaki Hanbelilik ile saray arasındaki gerilimin Avrupa'daki izdüşümü çok daha ileri aşamalara varmış olup; papa (kilise) ile kral (saray) arasında sıkı bir "temsil" (gölge) savaşı sahnelenmektedir. Ancak 16. yy.ın ilk yarısında Kopernik (1543) ile birlikte her iki taraf için de tehdit oluşturan bir "tehlike" baş gösterir. Evrenin "Dünya merkezli" olduğu fikrini reddi sadece astronomik bir olgu değil, siyasi sonuçları da olan bir devrimdir. Gökyüzüne ilişin algının değişmesi, yeryüzünde "tanrının gölgesi" olma iddiasındaki papanın da kralın da altındaki tahtın çekilmesi anlamına gelir.

Osmanlı'da da bilindiği üzere ilk rasathane 1570'li yıllarda III. Murat tarafından finanse edilerek gökbilimci Takiyuddin Mehmed tarafından kurulur. Ancak İstanbul'da tutucu çevreler tarafından çıkarılan "meleklerin bacaklarını izliyorlar" türünden dedi-kodular sonucu yine padişahın emriyle yıkılır. ${ }^{119}$ Avrupa'da ise Galileo gibi bilginler Engizisyonda yargılansa da Avrupa'nın içinde bulunduğu parçalanmışlık ve iç çelişkiler başkalarına modern astrofiziğin temellerini atacak çalışmalar için uygun ortamı sağlar. Böylece evren algısı değişen Batı'da (Modernite) "gökler" hakkındaki kabuller gittikçe teolojiden arınıp tanrı tasavvuru soyutlaşırken siyaset de günden güne sekülerleşir. Bundan böyle siyasi iktidarın meşruiyeti kozmik işaretler ya da kutsal soyla göklerden değil; halktan alınmak durumundadır (demokrasi). Evren fikrinin tümüyle değiştiği Batı'da siyaset felsefesinin yanı sıra maddi âlemle ilişki de değişir; bilimsel keşifler ve icatlar birbirini kovalar.

İslam dünyasında ise teolojik spekülasyonlarla kilitlenmiş siyasi-kültürel iklimde, dünya merkezli evren fikrine dayalı siyaset felsefesine etki edebilecek ne felsefi ne de bilimsel bir dinamik söz konusudur. Böylece Müslümanların Modernite ile ilişkisi sömürgecilikten ibaret kalır. Üstelik yüzyıllardır bir şekilde varlı̆̆ını devam ettiren Hanbeli öğreti Müslümanların zayıfladığı, Osmanlı'nın güçten düştüğü bir ortamda Vahhabilik suretinde sahneye daha bir cüretkâr çıar. Vahhabi isyanı $1813^{\prime}$ te Osmanlı kuvvetleri tarafından bastırılır ${ }^{120}$ ancak askeri olarak yenilse de politik bir öğreti olarak git gide güçlenen bu akım Arap milliyetçiliği ile de karışarak hızla Irak, Suriye ve Mısır gibi diğer Osmanlı Arap coğrafyasına yayılır. Irak'ta dönemin önemli din adamlarından Şeyh Ali esSüveydi (ö. 1921) Vahhabi faaliyetleri nedeniyle Osmanlı valisi tarafından takibata uğrayan isimlerdendir. Daha önce onun öğrencisi olmuş ve uzun süre Bağdat'a müftülüğü görevinde bulunmuş Ebu's Sena el Alusi de benzer suçlamalar nedeniyle görevinden azledilir. Ebu's Sena'nın oğlu Numan Alusi selefi düşüncesinin yaygınlaşmasında önemi bir rol oynar. İlk baskısı 1881 yılında gerçekleşen Celau'l Ayneyn adlı İbn Teymiyye'nin görüşlerinin propagandası mahiyetindeki kitabı oldukça etkili olur. Çıkardıkları el Menar dergisiyle Selefi öğretinin çok daha geniş kitlelere ulaşmasını sağlayan Reşit Rıza, kendisinde İbn Teymiyye ile ilgili müspet düşüncelerin bu kitap sayesinde oluştuğunu ifade eder. ${ }^{121}$

Kavramın yaygınlaşması bakımından önemli bir diğer isim de Suriye doğumlu Muhibbüddin el-Hatib'tir. Osmanlı idaresine karşı ayrılıkçı faaliyetlerde aktif olan El Hatib 1909'da Kahire'de "el Mektebetu's Selefiyye" adıyla yayınevi kurar. Ancak yayınların çeşitliliğinden de anlaşıldığı üzere El Hatib'in düşünce dünyası daha çok "Arap milliyetçiliği" şeklindedir. Nitekim El Hatib bu yöndeki dernekçilik-yayıncılık faaliyetlerinin devamı olarak I. Dünya Savaşı'nda Osmanlı'ya isyan başlatan Şerîf Hüseyin'in davetiyle (1916) Mekke'ye gider ve müsteşarlık görevinin yanı sıra yayıncılık faaliyetlerine de devam eder. Osmanlının tasfiye edildiği Dünya Savaşı sonrası tam bağımsızlık savaşları verilmiş ve ulus devletlerle yeni bir başlangıç yapılmışken savaşın hemen ardından Selefilik

\footnotetext{
119 Bkz. Türkân Alvan, “Devrinden Seyrine Sultan III. Murad'ın Kitâbü'l-Menâmât'taki Mektuplarına Dair Bazı Tespitler”, FSM İlmî Araştırmalar İnsan ve Toplum Bilimleri Dergisi, (Bahar 2014), 3: 52.

${ }^{120}$ Bkz. Fahir Armaoğlu, 19. Yüzyıl Siyası̂Tarihi (1789-1914), (Ankara: TTTK Basımevi, 1997), 197.

${ }^{121}$ Basheer M. Nafi, "Yeniden Dirilen Selefilik: Nu'man el Alusi ve İki Ahmed Muhakemesi", Marife, tec. Kadir Gömbeyaz, (Kış 2009), 3: 294.
} 
İslam ülkelerinde tekrar dal-budak salar. Özellikle Arabistan'da İngilizlerin Şerif Hüseyin'i tasfiye edip Suudi hanedanıla Vahhabi bir rejime yol vermeleri belirleyici olur. Arap dünyasında 50'lerde ve 60'larda yoğun tartışmalara neden olan Selefilik Türkiye'ye de bu yıllarda girer. Özellikle Müslüman Kardeşler, Pakistan'dan ise Cemâati İslami kitapları arayış içerisindeki gençlerin önüne serilir. Seyyid Kutub'un Din Dediğin Budur (1964) ve Yoldaki İşaretler (1966) ${ }^{122}$, Mevdudi'nin (ö. 1979) İslâm'da İhya Hareketleri (1967) adlı kitapları Hilal Yayınları tarafından Türkçeye taşınır. ${ }^{123}$ Hilal Yayınları, 1983'te Suudi Faysal Finans'ı Türkiye'ye getiren Salih Özcan tarafından 1955 yılında kurulmuştur. Benzer içerikli çok sayıda kitap, kurulacak başka yayın evleri tarafından da yıldan yıla artarak çoğalacaktır. Temel söylemi İbn Teymiyye'nin sözlerinin tekrarından ibaret “beşeri kanunlara karşı olmak" olan bu kitaplara göre insanların kanun yapması Allah'ın ulûhiyetine bir saldırıdır. Bu saldırının siyasal kurama dönüştüğü demokrasi de insanoğlunun ilahlık taslamasıdır. Kur'an'a Göre Dört Terim adlı eserinde düşünce dünyasını özetleyen Mevdudi “İlah” kavramını açıklarken bazı Kur'an ayetlerinden hareketle şöyle der:

... Bu son ayetlerden kaynak ve temel olarak yüce Allah'ın hükmüne, O'nun vazettiği ölçülere dayanmadıkları halde bireysel ve toplumsal planda genel bir hayat düzeni olarak din ya da şeriat yerine ikame edilen beşer ürünü yasaları, ilke ve töreler dizgesini olumlayıp bunlara teslim olmanın da şrk tavrının kapsamı içine girdiği, yani bu yasaları, ilke ve töreleri koyan kişilere bilerek, isteyerek boyun eğmenin de onları yüce Allah’a ortak koşmakla aynı anlama geldiğini öğrenmiş oluyoruz. ${ }^{124}$

Mevdudi gibi demokrasinin iflasın ${ }^{125}$ ilan eden Kutub'un eserlerinde temel vurgu "beşer aklının ürünü" yasalar ve ideolojiler sorunudur. Mevdudi de Kutub da, "beşeri ideolojiler" tanımlamasını o kadar geniş tutar ki, bildik anlamda "ideolojiler" bir yana, ilgili-ilgisiz her türlü düşünce sistemi ve felsefi görüş bir "beşer düşüncesi" olduğundan bu tanıma dâhil edilerek, "din" olarak nitelenir ve İslam'ın karşısına konumlandırılır:

...Bu "cahiliye", Allah'ın yeryüzündeki otoritesine, özellikle, "ulûhiyet" haklarına saldırı temeli üzerine kurulmuştur. Özellikle Allah'ın hâkimiyetine saldırı temeline... Söz konusu "cahiliye" anlayışı otoritesini, insanlığa dayandırır; insanların bir kısmını diğer kısmının tanrısı (rabbi) yapar. Fakat günümüz cahiliyesi ilk dönem cahiliye anlayışının kullandığı ilkel yöntemlerle bunu yapmaz, Allah'ın hayat için koyduğu ilahi yönetimi köşeye atarak, Allah'ın onayı olmayan alanlarda, değerlerde, yaşama düzeni ve yasalarda, tutum ve davranışlarda kendine özgü bir "dünya görüşü" koyma hakkına sahip olması şeklinde yapar. ${ }^{126}$

Aynı minvalde kitapları çevrilen Said Havva'ya göre de demokrasi insanlara "helal-haram koyma yetkisi" verme anlamina gelmektedir:

Demokrasi seçimle iş başına gelen ve başka bir kurumla temsil edilen (çoğunluk egemenliğine dayanan) sistemdir. Seçimle iş başına gelmiş meclis veya kurul dilediği gibi kanun koymaya yetkili sayılmaktadır. Zaten anayasalar birtakım mercilerin sınırsız görüş ve düşünceleriyle hazırlanmaktadır. İşte böyle bir sistem ve kanun koyma, helal kılma ve haram kılma yetkisi doğrudan doğruya insanlara verilmektedir ki bu da şirk'dir.127

\section{Sonuç}

Selefi yapıların, uzun süre İslam coğrafyasıyla sınırlı kalan faaliyetleri Soğuk Savaş'ın bitişiyle dünyanın başka coğrafyalarına da taşındı. Eylemlerin kabul edilemezliği karşısında Müslüman kitleler tarafından bu organizasyonların İslam'ı temsil etmedikleri söylense de konunun teorik temellerine dayalı yeterli bir izahının yapıldığı da söylenemez. Dünyadaki kontrol mekanizmasının

\footnotetext{
${ }^{122}$ Hilal Görgün, "Seyyid Kutub",Türkiye Diyanet Vakfı İslâm Ansiklopedisi, (İstanbul TDV Yayınları 2009), $37: 64$.

${ }^{123}$ Anis Ahmad, "Mevdudi", Türkiye Diyanet Vakfı İslâm Ansiklopedisi, (Ankara TDV Yayınları 2004), 29: 432.

${ }^{124}$ Ebu'l Ala Mevdudi, Kur'an'a Göre Dört Terim, trc. Cahit Koytak, (İstanbul: İdeal Kitaplar, 1997), 34.

${ }^{125}$ Seyyid Kutub, Yoldaki İşaretler, trc. Abdi Keskinsoy, (İstanbul: Pınar Yayınları, 1997), 7.

${ }^{126}$ Kutub, Yoldaki İsaretler, 12.

127 Said Havva, Şehadet, trc. Kenan Gültürk, (İstanbul: Ravza Yayınları, 2018), 116.
} 
geldiği dikkate alındığında uluslararası sistem açısından irtibatları belirsiz bu yapıların faaliyetleri Müslümanlar açısından daha uzun süre can sıkıcı olacak görünmektedir. Ancak kendilerinden başka hemen herkesi "tekfir" etmelerine rağmen "ümmet adına" hareket ettiklerini iddia eden bu yapılar karşısındaki yetersizliğin önemli bir nedeni, tarihinde yaşanmış ve Müslümanların din algısını belirlemiş temel hadiselerde yattığ da bir gerçektir. Buna göre tarihsel temellere inilmeden bu sorunların üstesinden gelinmesi de mümkün görülmemektedir. Tanrıya "oğul isnadı" (Hıristiyanlık) ya da "tanrıyla güreş tutan peygamber" (Yahudilik) gibi temel metinleri mitolojik imgelerle dolu diğer dinlerle kıyaslandığında, yalın Tevhit öğretisi ve felsefi tutarlılığı ile İslam’ın, modern çağın insanına en yakın din dili olduğu rahatlıkla söylenebilir. Ancak Müslüman entelektüellerin, tarihte cereyan etmiş siyasi süreçlerle belirlenmiş hâkim din yorumuna ilişkin geçmişin muhasebesini yapma ve felsefi düşünce geliştirme konusundaki çekinceleri, İslam'ın özündeki yalınlığı ile bu çağa hitap eden bir dil inşası önünde bir engel olarak durmaktadır. Oysa "Büyük Anlatıların” bittiği, insanlığın nihilizime sürüklendiği çă̆ımızda 1400 yıl önce putçu-tefeci-köleci düzenleri yıkan İslam'ın tevhitadalet-özgürlük çağrısı her zamankinden çok daha fazla ihtiyaç olarak kendisini göstermektedir. Ancak bu çağrı, karanlık yapıların sabotajlarından sıyırılmış, Âdemoğlunun yetkinliğine inanan, Allah'ın yaratmadaki gayesini (hikmet) sahiplenmiş bir akıl ile ifadesini bulabilir. Sorunlar karşısında mesuliyet duygusuyla davranmak yerine İslam'ın/Kur'an'ın bir siyaset felsefe ya da yönetim modeli önermediği şeklindeki yüz yıllık klişe söylemler, Batı karşısındaki yılgınlık ve çaresizliğin ifadesi olup Hz. Peygamber'in kurduğu toplum düzenini ve ilk dört halife döneminde yaşanan şura tartışmalarını görmezden gelmek anlamına gelir. Hz. Peygamber'in pratiği ve Kur'an'ın vaz ettiği ilkeler esasınca bir siyaset kuramı geliştirmekten imtina etmek, sadece sorumluluktan kaçmak ve Müslüman kitleleri, Batı düşüncesi ve selefi öğreti arsasında tercih durumuyla baş başa bırakmaktan başka bir anlam ifade etmemektedir.

\section{Kaynakça}

Abdurrazık, Ali. İslam'da İktidarın Temelleri. trc. Ömer Rıza Doğrul, İstanbul: Birleşik Yayınları, 1995. Ahmad, Anis. "Mevdudi". Türkiye Diyanet Vakfı İslâm Ansiklopedisi 29: 432-437. Ankara: TDV Yayınları 2004.

Alvan, Türkân. “Devrinden Seyrine Sultan III. Murad'ın Kitâbü'l-Menâmât'taki Mektuplarına Dair Bazı Tespitler". FSM İlmî Araştırmalar İnsan ve Toplum Bilimleri Dergisi 3 (Bahar 2014): 27-60.

Armaoğlu, Fahir. 19. Yüzyıl Siyası̂Tarihi (1789-1914). Ankara: TTTK Basımevi, 1997.

Askalani, İbn Hacer. El İsabe fi Temyizi's Sahabe. Cilt 5. Beyrut: Mektebetu'l Asriyye, 2012.

Askalani, İbn Hacer. Silsiletu'z Zeheb. Beyrut: Daru'1 Marife, 1986.

Ayverdi, Ekrem Hakkı. Osmanl Mimarisinde Fatih Devri. Cilt 4. İstanbul: Baha Mtb, 1974.

Başer, Sait. Kutadgu Bilig'de Kut ve Töre. İstanbul: İrfan Yayınları, 2011.

Bedirhan, Yaşar. İslam Öncesi Türk Tarihi ve Kültürü. Konya: Eğitim Yayınları, 2019.

Belazuri. Ensabu'l Eşraf, Beyrut: Daru'l Fikr, 1996.

Büyükkara, Mehmet Ali. Çağdaş İslami Akımlar. İstanbul: Klasik Yayınları, 2015.

Büyükkara, Mehmet Ali. İmamet Mücadelesi ve Haşimoğulları. İstanbul: Rağbet Yayınları, 1999.

Cevdet Paşa, Ahmet. Peygamberler ve Halifeler Tarihi, Cilt 1. İstanbul: Merve Yayınları, (tarihsiz).

Çavuşoğlu, Semiramis. "Kadızâdeliler". Türkiye Diyanet Vakfı İslam Ansiklopedisi 24: 100-102. İstanbul: TDV Yayınları, 2001.

Çelebi, İlyas. "Hızlan”. Türkiye Diyanet Vakfı İslam Ansiklopedisi 17: 419-420. İstanbul: TDV Yayınları, 1998.

Dalgın, Nihat. “İbn Lehîa”. Türkiye Diyanet Vakfı İslam Ansiklopedisi 20: 158 - 159. İstanbul: TDV Yayınları 1999.

Dannenbauer, Heinrich. Grundlagen der Mittelalterlichen Welt, Skizzen und Studien. Stuttgart: W. Kohlhammer Vrl. 1958. 
Dönmez, İbrahim Kafi. “İcmâ”. Türkiye Diyanet Vakfı İslam Ansiklopedisi 21: 417-431. İstanbul: TDV Yayınları, 2000.

Eba Zeyd, Sâbir Abduh. Minhâcü Ehli's Sünne. İskenderiyye: Dârü'l-Vefâ, 2005.

Ebu Amr, Hay bin Salim El Hay. Et Temyiz. Kuveyt: Garas li'n Neşr, 2007.

Ebu Hanife. “Fıkhu'l Ekber”, İmam-ı A'zam’ın Beş Eseri. Trc. Mustafa Öz. İstanbul: İFAV, 2017.

Ebu Nuaym. Kitabu'l İmame. Medine: Mektebetu'l Ulum ve'l Hikem, 1987.

Ebu Zehra, Muhammed. Ebu Hanife. Kahire: Daru'l Fikr el Arabi, 1955.

Elsner, Hildegard \& Reichardt, Hans. Die Germanen. Nürnberg: Tessloff Vrl., 2008.

Eş'ari, Ebu'l Hasan. El Lüma. Beyrut: Daru'l Kutubu'l İlmiyye, 1971.

Eş'ari, Ebu'1 Hasan. Makalatu'l İslamiyyin. Cilt 2. Beyrut: El Mektebetü'l Asriyye, 1990.

Eş'ari, Ebu'l Hasan. Risaletu İstihsanu'l Havz fi İlmi'l Kelam. Haydarabad: İdaretu'1 Maarif el Osmaniyye, 1979.

Eş'ari. El İbane. Dimaşk: Daru'1 Beyan, 1990.

Gavci, Vehbi Süleyman. Ebu Hanife Numan. Dımaşk: Daru'l Kalem, 1999.

Gazali. El Munkızu min ed Dalal, Trc. Hilmi Güngör. Ankara: MEB Yayınları, 1960.

Gazzali. İhyâu Ulûmi'd Dîn. Cilt 3. Trc. Ahmet Serdaroğlu. İstanbul: Bedir Yayınları, 2002.

Görgün, Hilal. "Seyyid Kutub". Türkiye Diyanet Vakfı İslâm Ansiklopedisi 37: 64-68. İstanbul: TDV Yayınları, 2009.

Görmez, Mehmet. "İslam Dünyasında Laiklik Tartışmasını Başlatan Bir Kitap ve Bu Kitabın Serencamı". İslami Araştırmalar Dergisi 8/3-4 (Yaz-Güz 1985): 256-263.

Güzel, Fatih. "Abbâsî Halifesi Mütevekkil'in Türk Nüfuzunu Sonlandırma Çabaları". KAREFAD 4/2. (2016): $117-132$.

Hanbel, Ahmed bin. er Red ale'l Cehmiyye ve'z Zenâdıka. Riyad: Dâru's Sebât, 2003.

Hanbel, Ahmed bin. Müsned, Cilt 16. Kahire: , Daru'l Hadis, 1995.

Havva, Said. Şehadet. Trc. Kenan Gültürk. İstanbul: Ravza Yayınları, 2018.

Hereri, el Uremi. Tefsiru'l Hadâiku'r Ruh ve er Reyhân. Beyrut: Daru't Turuk, 2001.

Hilali, Salim bin Zekvan. Es Sîre. Trc. Harun Yıldız. Ankara: Ankara Okulu Yayınları, 2017.

Hüseyin, Taha. Min Târih el Edeb el Arabi - El-Asru'l Abbâsîyyi el Evvel. Cilt 2. Beyrut: Dâru'l İlm li'l Melâyîn, 1971.

İbn Âdil. El Lübab fi Ulumi'l Kitab. Cilt 20. Beyrut: Daru'l Kütübi'l Iilmiyye, 1998.

İbn Asâkir. Târîhu Medîneti Dımaşk. Cilt 30. Beyrut: Daru'1 Fikr, 1995.

İbn Cevzi. el Mevzuât. Cilt 1. Medine: Mektebetu's Selefiyye, 1966.

İbn Haldun. Mukaddime. Cilt 1. Beyrut: Dâru'l Fikr, 2001.

İbn Hişam. Es Siretü'n Nebeviyye. Cilt 2. Beyrut: Darü'1 Kitabil Arabi, 1990.

İbn Kesir. Büyük İslam Tarihi (El Bidaye). Cilt 8. Trc. Mehmet Keskin. İstanbul: Çağrı Yayınları, 1994.

İbn Kesir. Tefsîrü’l Kur'âni'l Azîm. Cilt 8. Riyad: Dâru't Tayyibe, 1999.

İbn Kuteybe. El İmame ve's Siyase. Beyrut: Dâru'l Edvâ, 1990.

İbn Mukaffa. Âsâru İbni'l-Mukaffa, Beyrut: Dâru'l Kütübi'l İlmiyye, 1989.

İbn Sa'd. Et Tabakatu'l Kübra. Cilt 1. Beyrut: Daru'l Kutubu'l İlmiyye, 1990.

İbn Teymiyye. Mecmu'u'l Fetava. Cilt 12. El Mansure: Darul Vefa, 2005.

İbnu'l Arîf. Miftâhu's Saâde. Beyrut: Dar'ul Garb el İslami, 1993.

İbnü'l Esir. El Kâmil fi't Tarih. Beyrut: Daru'l Kutubu'l İlmiyye, 1987.

İğde, Muhyettin. Siyasi-İtikadi Bir Mezhep Olarak Hanbeliliğin Teşekkül Süreci. İstanbul: MÜ İlahiyat Fakültesi Vakfı Yayınları-İFAV, 2016.

İnalcık, Halil. Osmanlı'da Devlet, Hukuk, Adalet. İstanbul: , Eren Yayınları 2005.

İpşirli, Mehmet. “Osmanlı Devleti'nde Kazaskerlik (XVII. yüzyıla kadar)”. Belleten 61/232. (1997): 597700.

Kanunname-i Âl-i Osman. Tarih-i Osmani Encümeni Mecmuasının İlavesi, Ahmed İhsan Şürekası Matbaacılık Osmanlı Şirketi İstanbul: 1329. 
Kastallani. El Mevâhibü'l Ledünniyye. Cilt 2. Beyrut: El Mektebu'l İslami, 2004.

Kaysi, Abdulkadir Muhammed. İctihad ve't Taklid fi'ş Şeriati'l İslamiye ve Ebi Hanife en Numan. Beyrut: Daru'1 Kutubu'l İlmiyye, 2019.

Kervegan, Jean François. “Demokrasi”. Siyaset Felsefesi Sözlüğ̈̈, Trc. İsmail Yerguz. İstanbul: İletişim Yayınları, 2011.

Kilavuz, Ahmet S. "Berbehârî". Türkiye Diyanet Vakfı İslam Ansiklopedisi 5: 476-477. İstanbul: TDV Yayınları, 1992.

Kutub, Seyyid. Yoldaki İşaretler. Trc. Abdi Keskinsoy, İstanbul: Pınar Yayınları, 1997.

Mardin, Şerif. Din ve İdeoloji. Ankara: Sevinç Mtb., 1969.

Mavil, Hikmet Yağlı. "Eş'ariyye'nin Kurucusu Ebü'l-Hasan el-Eş'arî". Uludă̆ Üniversitesi İlahiyat Fakültesi Dergisi 21 (Haziran 2012): 69-91.

Mertoğlu, M. Suat. “Ümmi”. Türkiye Diyanet Vakfi İslam Ansiklopedisi 42: 309-310. İstanbul: TDV Yayınları, 2012.

Mervezi, Ahmed bin Ali. Es Sünne. Riyad: Daru'l Asime, 2001.

Metiner, Mehmet. Yemyeşil Şeriat, Bembeyaz Demokrasi, İstanbul: Karakutu Yayınları, 2008.

Mevdudi, Ebu'l Ala. Kur'an'a Göre Dört Terim, Trc. Cahit Koytak, İstanbul: İdeal Kitaplar, 1997.

Müslim. El Camiu's Sahih. Cilt 1. Beyrut: Dârü't Kutubi'l İlmiyye, 1991.

Nafi, Basheer M. "Yeniden Dirilen Selefilik: Nu'man el Alusi ve İki Ahmed Muhakemesi". tec. Kadir Gömbeyaz. Marife 3, (Kış 2009): 293-326.

Nu'aym bin Hammad, Ebu Abdullah. Kitabu'l Fiten. Kahire: Mektebetu't Tevhîd, 1991.

Özkan, Halit. "Zühri”. Türkiye Diyanet Vakfi İslam Ansiklopedisi 44: 544-549. İstanbul: TDV Yayınları, 2013.

Rafii. el-aziz Şerhü'l Veciz. Beyrut: Darü'l-Kütübi'l-İlmiyye, 1997.

Salih es Seyyid, Muhammed. Amr b. Ubeyd ve Ârâuhu el Kelamiyye. Kahire: , Mektebetu Nahdati'ş Şark, 1985.

Sezgin, Fuat. Tanınmayan Büyük Çağ. İstanbul: Timaş Yayınları, 2010.

Sivrioğlu, U. Töre. “İbn Teymiyye'nin Siyaset, Hukuk Ve İktisat Teorisi”. Yönetim ve Ekonomi Araştırmaları Dergisi 20 (2013): 88-104.

Suyuti. Ed Dürrü'l Mensur fi't Tefsiri'l Me'sur. Beyrut: Darü'l Fikr, 2011.

Suyuti. Miftahu'l Cenne. Kahire: El İdâretu't Tıbâatu'l Münîriyye, 1928.

Şehristani. Milel ve Nihal. Trc. Mustafa Öz. İstanbul: Litera Yayınları, 2011.

Taberi. Târîhu'r Rusül ve'l Mülûk. Kahire: Dârü'l Me'ârif, 1967.

Taftazani. Şerhu'l Akâid. Trc. Süleyman Uludağ. İstanbul: Dergah Yayınları, 1991.

Ubeydi, Muhammed bin Abdurrahman. Et Tezkiretü's Sadiyye fi'l Eş'ari'l Arabiyye. Beyrut: Dâru'l Kütübi'l İlmiyye, 2001.

Wilcken, Ulrich. Griechische Geschichte im Rahmen der Altertumsgeschichte. München: R. Oldenbourg Vrl., 1973.

Yarman, Rahmi. "Bidat". Türkiye Diyanet Vakfı İslam Ansiklopedisi 6: 129-131. İstanbul: TDV Yayınları, 1992.

Yiğit, İsmail. “Osman”. Türkiye Diyanet Vakfı İslam Ansiklopedisi 33: 438-443. İstanbul: TDV Yayınları 2007.

Yücel, Ahmet. "Kitabet". Türkiye Diyanet Vakfı İslam Ansiklopedisi 26: 81-83. Ankara: TDV Yayınları, 2002.

Zemahşeri. Keşşaf. Cilt I. Riyad: Mektebetu'l Abikân, 1998. 